\title{
Fluoride Variations in Rivers on the Slopes of Mount Meru in Tanzania
}

\author{
Aldo J. Kitalika $(\mathbb{D}$, Revocatus L. Machunda, Hans C. Komakech, and Karoli N. Njau \\ Department of Water and Environmental Science and Engineering, Nelson Mandela African Institute of Science and Technology, \\ P.O. Box 447, Tengeru, Arusha, Tanzania
}

Correspondence should be addressed to Aldo J. Kitalika; kitalikaa@nm-aist.ac.tz

Received 17 August 2017; Revised 2 December 2017; Accepted 13 December 2017; Published 23 January 2018

Academic Editor: Maurizio Barbieri

Copyright (C) 2018 Aldo J. Kitalika et al. This is an open access article distributed under the Creative Commons Attribution License, which permits unrestricted use, distribution, and reproduction in any medium, provided the original work is properly cited.

\begin{abstract}
This study reports the variations of fluoride ions in rivers on the slopes of Mount Meru in the northern part of Tanzania. More than 318 water samples were collected from Temi, Nduruma, Tengeru, and Maji ya Chai Rivers in both wet (mid-March and April) and dry (August) seasons. The samples were analyzed for fluoride levels using Ion Selective Electrode (ISE). The minimum and maximum average fluoride levels in the wet season were $0.24 \pm 0.03 \mathrm{mg} / \mathrm{l}$ and $65.20 \pm 0.03 \mathrm{mg} / \mathrm{l}$, respectively, whereas the average lowest and highest levels in the dry season were $1.02 \pm 0.02 \mathrm{mg} / \mathrm{l}$ and $69.01 \pm 0.03 \mathrm{mg} / \mathrm{l}$, respectively. Tengeru River had the lowest fluoride levels in both seasons, whereas Maji ya Chai recorded the highest fluoride levels in both seasons. The headwater of all rivers with the exception of Maji ya Chai met the World Health Organization's (WHO) maximum acceptable fluoride levels of $1.50 \mathrm{mg} / \mathrm{l}$ and the downstream environment qualified for Tanzania Bureau of Standards (TBS) maximum permissible fluoride concentration in drinking water of $4.00 \mathrm{mg} / \mathrm{l}$. Also, the laboratory experiments showed that fluoride containing rocks exposed to $\mathrm{pH}$ above 7.6 display high leaching of $\mathrm{F}^{-}$in solution which gradually increased with the increase in $\mathrm{pH}$, indicating that dissolution of fluoride in water is a function of $\mathrm{pH}$.
\end{abstract}

\section{Introduction}

The understanding of fluoride distribution in Tanzanian rivers is of great importance since majority of the Tanzanian population obtain their domestic freshwater from rivers, springs, and lakes. It is reported that $30 \%$ of these are water sources with fluoride concentration exceeding $1.5 \mathrm{mg} / \mathrm{l}$ [1]. Despite the fact that fluoride has health benefits, consumption above the optimal level is unhealthy. The WHO and TBS recommend that the healthy intake of fluoride in water should not exceed $1.5 \mathrm{mg} / \mathrm{l}$ and $4.0 \mathrm{mg} / \mathrm{l}$, respectively $[2,3]$. Excessive consumption of fluoride has been shown to cause crippling skeletal fluorosis due to the reaction of $\mathrm{F}$ and $\mathrm{Ca}$ in the bones; thus, it is extremely reactive in biological systems, thus affecting the enzymes and the whole organism as well $[4,5]$. In Tanzania, fluorides are distributed in the regions of Arusha, Moshi, Singida, and Shinyanga, with a severely affected area being on the foothills of Mount Meru and Kilimanjaro [6, 7]. Fluoride-rich waters are associated with sediments of marine origin in mountainous areas and volcanic, granitic, and gneissic rocks [8]. Being the case in Tanzania, the problem occurs both in the rift valley zones in the northern and southwestern part of the country associated with volcanic activity and in the crystalline basement complex of the central plateau [9]. Enrichment of fluoride minerals in water occurs through evaporation, weathering of volcanic rocks, and geothermal solutions in the rift valley system, as well as dissolution from saline rocks associated with fluoride $[9,10]$.

Fluorine is the most electronegative element with the electronegativity value of 3.98 on the Pauling Scale; thus, it is very reactive [11]. Therefore, this property makes the element exist in different forms of mineral salts in the environment rather than in its pure form [12]. The fluoride containing minerals are grouped into fluorides, phosphates, silicates, and mica [13]. In Tanzania, fluorapatite, fluorite, topaz, phlogopite, and lepidolite predominate. All these minerals are water-insoluble and hence their ability to release fluoride ions in surface and groundwater depends on the conditions which favor their solubility such as high temperature and 
$\mathrm{pH}$. Therefore, fluorides enter surface water by leaching (being the main cause) and surface runoff from fertilizers containing phosphates, industrial emissions, and effluents [14]. The average dissolved fluoride content in major rivers of the world is between $0.01 \mathrm{mg} / \mathrm{l}$ and $0.02 \mathrm{mg} / \mathrm{l}$, whereas in lakes it is below $0.5 \mathrm{mg} / \mathrm{l}$ [3], but in Tanzania the concentrations are above the mentioned values in the vulnerable regions [14].

Previous studies carried out to establish sources of high fluoride concentrations and distribution in the environment on the slopes of Mount Meru have mostly put emphasis on groundwater. In surface water, studies reported the fluoride levels of 12-13 mg/l, 21-26 mg/l, 61-65 mg/l, and $690 \mathrm{mg} / \mathrm{l}$ for Maji ya Chai and Engare Nanyuki Rivers, pond water, and Lake Momela, respectively [9, 14-18]. The contaminated areas have shown health implications to some children and adults living around the foot of Mount Meru [5, 15]. Further studies on fluoride levels were carried out in groundwaters within the same area and found a concentration of up to $68 \mathrm{mg} / \mathrm{l}$ which was highly associated with the alkaline volcanism and high $\mathrm{pH}[19,20]$. The vulnerability of alkaline soil for fluoride dissolution in soil has recently been associated with the presence of bicarbonate ions $\left(\mathrm{HCO}_{3}{ }^{-}\right)$, which accelerates the alkalinity and fluoride availability [21]. Since surface/river water is a contribution of groundwater discharge and precipitation, fluorides in water are mainly from leaching of rocks from groundwater and fluoride containing stuff.

Despite the above facts, the general trends of fluorides in rivers after interaction with different environments of this study area have been little studied and mapped, thus raising the importance of this study. Thus, this work was conducted to investigate the spatial distribution of fluorides in rivers after such interactions have occurred together with tracing their point sources of contamination, if any. Studies in these rivers are of profound importance since water from these rivers is used in various domestic activities including cooking and drinking in Arusha City.

\section{Materials and Methods}

2.1. Description of the Study Area. The study area involved four rivers, namely, Temi and Nduruma which lie within the Arusha City and Tengeru and Maji ya Chai which lie within the Meru District. The four rivers originate from a common subcatchment of foothills of Mount Meru lying from the eastern part to the southwest of the mountain (Figure 1). The rivers run downstream from the mountain to the southeast. Natural vegetation is typically tropical forest to savannah. The topography of the study region is dominated by the Mount Meru volcanic cone of Pleistocene to recent origin. The local climate of the area is temperate Afro-Alpine, with an annual precipitation of $450 \mathrm{~mm}$ [22] and mean minimum and maximum daily temperature of $20.6^{\circ} \mathrm{C}$ and $28.5^{\circ} \mathrm{C}$, respectively. Rainfall is irregularly distributed between a main wet season from February to mid-May (contributing $70 \%$ of the annual precipitation) and a minor one from September to November which provides much of the remainder giving the mean annual rainfall of $535.3 \mathrm{~mm}$. The remaining months are effectively dry, although occasional showers do occur during this period $[23,24]$. The four rivers contribute to the Pangani basin subcatchment feeding the Pangani River. The study area was divided into three regions depending on the river and land development, namely, pristine (headwater) $\left(3^{\circ} 15^{\prime} 00^{\prime \prime} \mathrm{S}\right.$ to $\left.3^{\circ} 20^{\prime} 00^{\prime \prime} \mathrm{S}\right)$, middle $\left(3^{\circ} 20^{\prime} 00^{\prime \prime} \mathrm{S}\right.$ to $\left.3^{\circ} 25^{\prime} 00^{\prime \prime} \mathrm{S}\right)$, and flood plain $\left(3^{\circ} 25^{\prime} 00^{\prime \prime} \mathrm{S}\right.$ to $\left.3^{\circ} 35^{\prime} 00^{\prime \prime} \mathrm{S}\right)$. The catchment area for the rivers is considered as pristine (headwater) which is characterized by artificial and natural forest conservation, the middle area of the river consists of mixed peasant agriculture and human settlement, and the floodplain is the downstream area of the river characterized by bare land, intensive grazing, large-scale agriculture, and serious flooding in wet season.

2.2. Sampling. The GPS predetermined sampling points were identified based on confluence, accessibility, and preestablished monitoring stations. Two-liter water samples were collected in each point downstream from the source of each river (Figure 1). One-liter water sample was used for chemical parameter measurement and the second liter for fluoride and nutrients measurement. Sampling was done thrice in oneweek interval during the wet season (mid-March to early April) and dry season (August) in 2015. In each season, 159 representative samples were collected for analysis.

2.3. Chemicals. Analytical-grade reagents from SigmaAldrich (Merck) for the preparation of TISAB II and TISAB IV were prepared from glacial acetic acid, $\mathrm{NaCl}, \mathrm{NaOH}, \mathrm{HCl}$, tris(hydroxymethyl) amino methane, and sodium tartrate dihydrate, respectively. Also, the analytical grade of Ion Electrolyte Reference Filling Solution (P/N 51344750) was obtained from the same company.

2.4. Extraction, Pretreatment, and Cleanup of Water Samples. Samples for major ions measurements were not pretreated with any chemical except for the samples with solids and other organic debris that were filtered using a $0.45 \mu \mathrm{m}$ filter before measurement. Samples for $\delta^{18} \mathrm{O}$ and $\delta^{2} \mathrm{H}$ analysis were kept cooled at $4^{\circ} \mathrm{C}$ before and on transport to the Stable Isotope laboratory at Waterloo University in Canada.

2.5. Detection Limit of the Instrument and Calibration. The calibrated detection limit of the instrument was reconfirmed by measuring in triplicate the serially diluted primary standard solution with the lowest concentration of $0.02 \mathrm{mg} / \mathrm{l}$, which was the calibrated minimum detection limit (MDL), and the maximum instrument detection limit was calibrated at $100 \mathrm{mg} / \mathrm{l}$. Therefore, any undetected concentration measurement of a highly diluted sample was regarded to be below $0.02 \mathrm{mg} / \mathrm{l}$ and thus it was below the detection limit (BDL) of the instrument and for the same purpose similar measurements in double distilled water used for rinsing apparatus, its cleaners and TISAB were all considered as fluoride-free matrices. 


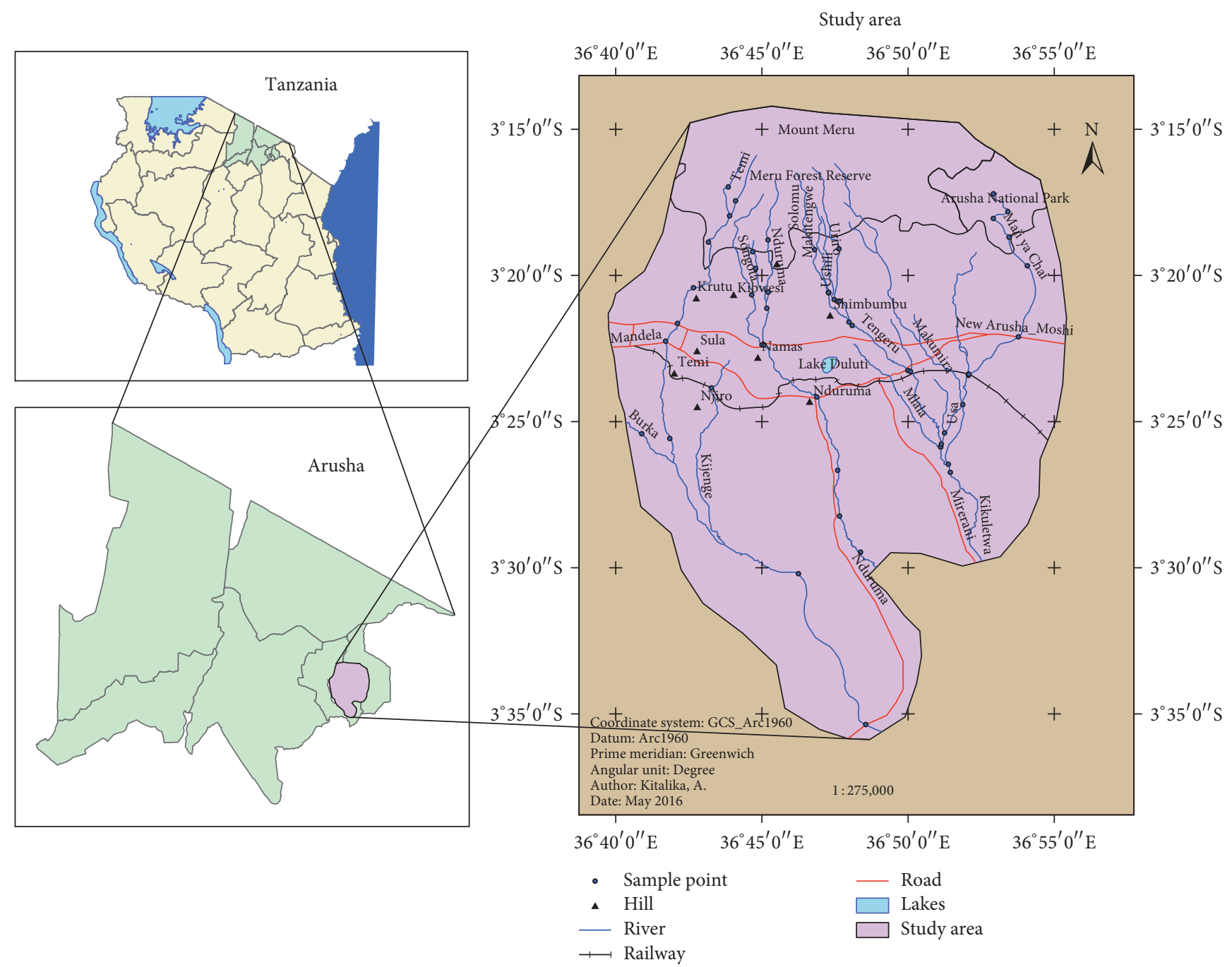

FIgURE 1: Location of the study area.

2.6. Analysis and Confirmation. The sample's physicochemical parameters (temperature, $\mathrm{pH}$, conductivity, velocity, and TDS) were measured in situ from the sampling points. Quantification of free fluoride ions was done by mixing equal volumes of Total Ionic Strength Adjustment Buffer (TISAB) to provide a constant background ionic strength, decomplex fluoride ions, and adjust the solution $\mathrm{pH}$. Thorough mixing was done using a magnetic stirrer. Measurement was done using the Ion Selective Electrode (ISE) from Mettler Toledo, perfectION ${ }^{\mathrm{TM}}$, with a Bayonet NeillConcelman (BNC) connector, P/N 51344775. The electrode was immersed in serially diluted fluoride primary standard solution of $0.1 \mathrm{mg} / \mathrm{l}$ and $10 \mathrm{mg} / \mathrm{l}$ from Sigma-Aldrich (Merck) for calibration, followed by measurement of the mixture, and the steady readout was recorded. The electrode was filled with Ion Electrolyte Reference Filling Solution (P/N $51344750)$ to maintain its maximum sensitivity. Analysis for $\delta^{18} \mathrm{O}$ and $\delta^{2} \mathrm{H}$ stable isotopes was done using a modern technology of Los Gatos Research Laser processes analyzer with Integrated Cavity Output Spectroscopy (LGR-ICOS ${ }^{\mathrm{TM}}$ ) machine using the Vienna Standard Mean Ocean Water
(VSMOW) with a standard error of $\pm 0.8 \%$. The experimental rock identification was done in the Geology Department of the University of Dar es Salaam (UDSM) using the Xray powder diffraction (XRD) machine. The geostatistical analyses for the spatial distribution of fluoride and other related parameters were done using ArcGIS software, version 10.1, in the GIS Laboratory of the Nelson Mandela African Institute of Science and Technology, Arusha, Tanzania.

2.7. Analytical Quality Assurance. Double-distilled water that was used for rinsing all the instruments and apparatus was tested to check whether it is fluoride-free before use. Instruments were rinsed thrice with double-distilled water to ensure no traces of fluoride outside the sample before another consecutive measurement was done. Thereafter, the glass electrode cleanliness was reconfirmed by immersing in a beaker containing distilled water, and its cleaners were measured for fluoride-free ions and thereafter TISAB solution was also measured for any traces of fluoride to assess its purity before measurement of the analyte was made. Also, 
the linearity of the electrode was monitored in every two samples' measurements by measuring a known concentration $(0.1 \mathrm{mg} / \mathrm{l}$ and $10 \mathrm{mg} / \mathrm{l}$ in serial dilutions $)$ primary standard fluoride solution.

2.8. Statistical Test. The strength of the linear relationships between fluoride levels with other physicochemical parameters was assessed by calculating Pearson's correlation coefficient $(r)$ using Sigma Plot software, version 11. Also, Student's $t$-test at the stated $p$ value was carried out to assess whether the fluoride levels between seasons are significantly different. Significant difference was considered when the $p$ values were $<0.05$.

2.9. Geostatistical Mapping. Fluoride concentration mapping was done by graduated symbols proportional to values using ArcMap version 10.1. The fluoride concentration ranges in water were grouped based on WHO $(0.0-1.5 \mathrm{mg} / \mathrm{l})$ and TBS (0.0-4.0 mg/l) standards simply for the purpose of assessing the status of the rivers according to the mentioned standards $[2,3]$.

2.10. Identification and Laboratory Experiments of Fluoride Leaching Rocks. A laboratory experiment was set up to assess the effect of $\mathrm{pH}$ in dissolution of fluoride containing rocks at $25^{\circ} \mathrm{C}$. Two rocks were collected in the catchment river banks of Nduruma and Tengeru Rivers and two more rocks were collected in Maji ya Chai River, whereby the first rock was collected from Maksoro (M1, area with low fluoride levels) and the second rock was collected from Jamera (M2, with high fluorides in water). The rock types were initially identified by X-ray powder diffraction (XRD) and confirmed to be feldspar-quartz extrusive volcanic igneous rocks. All rocks were separately ground at variable grain sizes (Table 5). A $2.00 \mathrm{~g}$ sample of each ground rock was mixed with $200 \mathrm{ml}$ of deionized water and the mixture was constantly stirred with a magnetic stirrer on a hot plate at $150 \mathrm{rpm}$ and $25^{\circ} \mathrm{C}$ for three consecutive days. Monitoring of fluoride concentrations was done every twelve hours on all days and the results were recorded.

\section{Results and Discussion}

The average physicochemical trends for the four rivers are shown in Tables 1 and 2. The fluoride levels in various points of the rivers are shown in Table 3. The isotopic signatures of $\delta^{18} \mathrm{O}$ and $\delta^{2} \mathrm{H}$ from the LGR-ICOS laser process analyzer of water in the four rivers in different points are shown in Table 4. The particle size distribution of the ground rock and its $\mathrm{pH}$ dependence for fluoride leaching results are shown in Tables 5 and 6, respectively.

\subsection{General Trends}

3.1.1. Isotopic characteristics of Water. Table 1 shows the different stable isotopic compositions of water on the slopes of Mount Meru. The oxygen and deuterium isotopic compositions of each river water on these slopes are controlled by meteoric precipitation, evaporation, and groundwater. There is a large difference between water from precipitation and running water with progressive variation from the catchment to the downstream. The isotopic data show enrichment downstream with an increase in water temperature (Figure 2). Such trend shows a sign of evaporation which can be an important factor contributing to the slight increase of some dissolved salts in water. Despite such isotopic variations, the data differ slightly from the Global Meteoric Water Line (GMWL) (Figure 2). Also, similar variations are noted within the river from the catchment area to the downstream. Such isotopic variations are further experienced in each river from the catchment to the downstream which can be caused by the different environments the rivers pass and groundwater recharged mixing with surface water.

Also, more observations show that ${ }^{2} \mathrm{H}$ and ${ }^{18} \mathrm{O}$ enrichment is relatively higher in Maji ya Chai and Temi Rivers; thus, it is expected that the evaporation effect will be much pronounced in the two rivers compared to Nduruma and Tengeru Rivers.

3.1.2. Physicochemical Trends. The $\mathrm{pH}$ of all rivers was above 7 in both seasons with the lowest $\mathrm{pH}$ being in the catchment areas of all rivers. The lowest $\mathrm{pH}(7.12 \pm 0.11)$ was measured at Tengeru catchment during the wet season whereas the highest value $(9.90 \pm 0.14)$ was measured in Nduruma River downstream during the dry season. Tengeru River showed the lowest $\mathrm{pH}$ in both seasons which averaged $7.12 \pm 0.11$ in the wet season and $7.70 \pm 0.36$ in the dry season. Maji ya Chai had the highest average $\mathrm{pH}$ in both seasons with the values of 8.03 \pm 0.57 and $8.57 \pm 0.52$ for wet and dry seasons, respectively (Figure 3$)$. The minimum water temperature $\left(12.21^{\circ} \mathrm{C}\right.$ ) was measured in the catchments area of Nduruma River with its highest temperature of up to $25^{\circ} \mathrm{C}$ being measured in the dry season. The lowest average temperature of $17.01 \pm$ $1.80^{\circ} \mathrm{C}$ was recorded at Temi River in the wet season while its highest temperature of $20.44 \pm 4.22^{\circ} \mathrm{C}$ was recorded in the dry season. The temperature variations in all rivers were generally associated with canopy cover of the riparian environment and its elevation such that the low water temperature was measured in high canopy cover environment and vice versa for the high water temperature.

The lowest conductivity of $82 \mu \mathrm{S} / \mathrm{cm}$ was measured at the catchments of Temi River, an indication of less salt being dissolved in it, whereas the lowest average value of 179.33 $\pm 26.73 \mu \mathrm{S} / \mathrm{cm}$ was measured at Nduruma River in the wet season. The highest EC of $1722 \mu \mathrm{S} / \mathrm{cm}$ was measured in the downstream of Maji ya Chai River during the dry season with the highest average value of $1183.43 \pm 47.54 \mu \mathrm{S} / \mathrm{cm}$ being in the same river.

3.1.3. Distribution of Major Cations and Anions in Rivers. The dissolved major cations and ions in the four rivers are shown in Tables 2 and 3. The data are further summarized in the Piper diagram as shown in Figure 3. For Temi River, neither ion predominated in both seasons; thus, the Ca-Mg or $\mathrm{Na}^{+}$ and $\mathrm{K}^{+}$were all very low with $\mathrm{SO}_{4}{ }^{-}, \mathrm{HCO}_{3}{ }^{-}$, and $\mathrm{Cl}^{-}$also being low, resulting in low EC and TDS and hence soft water. 


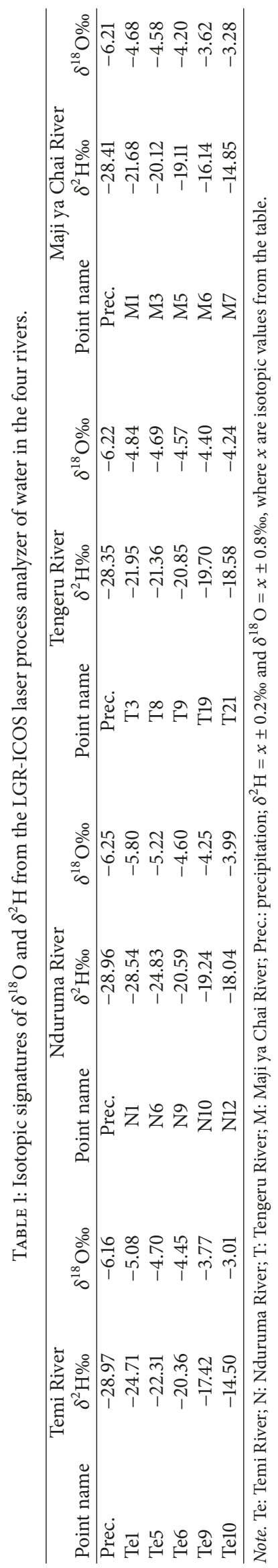




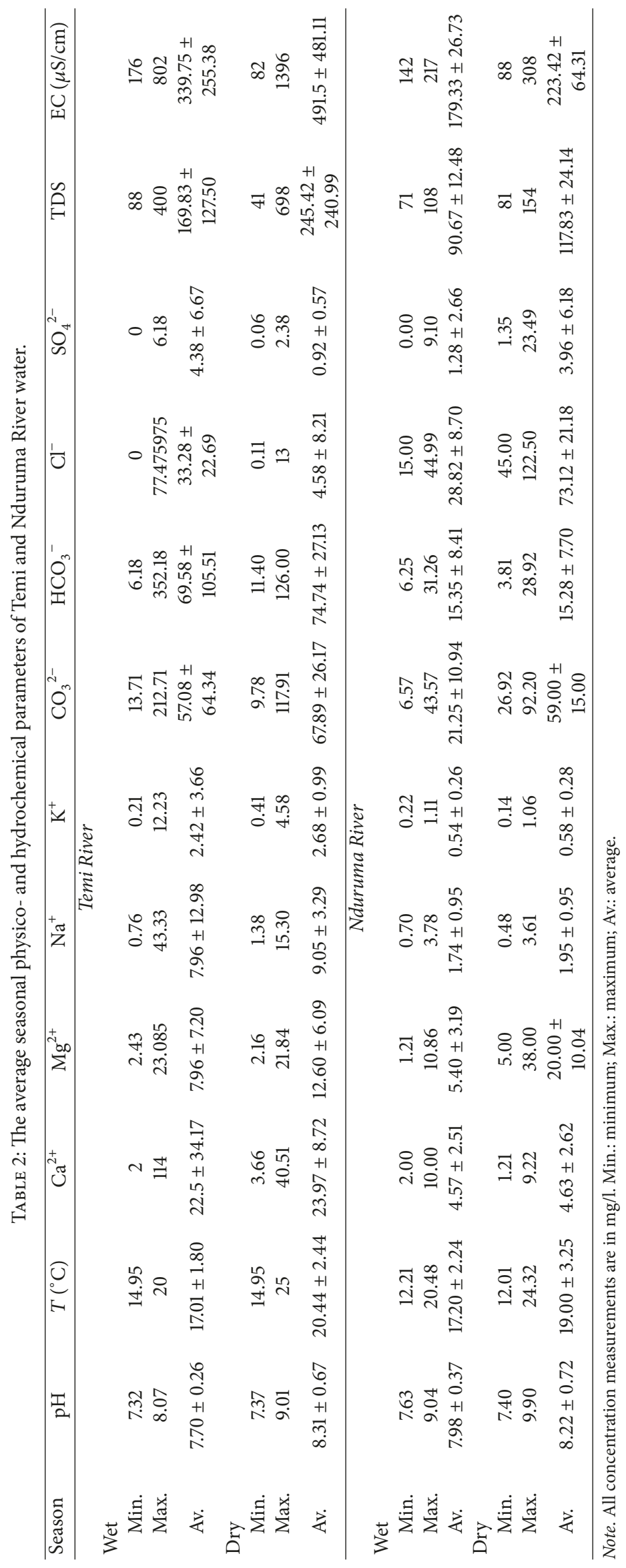




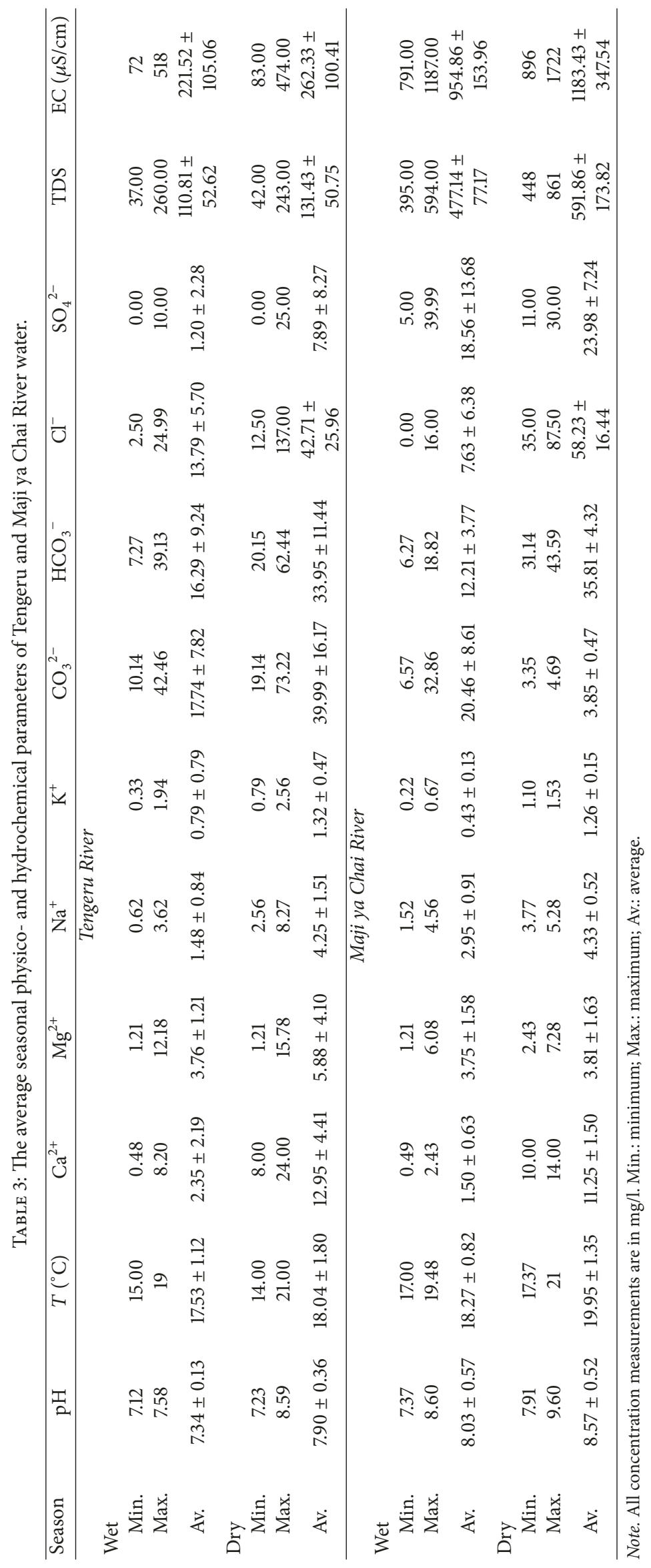


Table 4: Fluoride levels in Temi, Nduruma, Tengeru, and Maji ya Chai Rivers.

\begin{tabular}{|c|c|c|c|c|c|}
\hline Latitude & Longitude & Point code & River & $\mathrm{F}^{-}$_wet $(\mathrm{mg} / \mathrm{l})$ & $\mathrm{F}^{-}$ddry $(\mathrm{mg} / \mathrm{l})$ \\
\hline-3.318744 & 36.780114 & $\mathrm{~T} 1$ & Tengeru & 0.94 & 1.45 \\
\hline-3.343263 & 36.788113 & $\mathrm{~T} 2$ & Tengeru & 0.24 & 1.25 \\
\hline-3.318238 & 36.794051 & $\mathrm{~T} 3$ & Tengeru & 0.68 & 1.11 \\
\hline-3.343263 & 36.788113 & $\mathrm{~T} 4$ & Tengeru & 1.17 & 1.44 \\
\hline-3.343118 & 36.788072 & T5 & Tengeru & 1.48 & 1.51 \\
\hline-3.347191 & 36.791335 & T6 & Tengeru & 0.66 & 0.97 \\
\hline-3.343113 & 36.788064 & $\mathrm{~T} 7$ & Tengeru & 1.32 & 1.50 \\
\hline-3.361913 & 36.801558 & $\mathrm{~T} 10$ & Tengeru & 1.20 & 1.56 \\
\hline-3.387562 & 36.833290 & T11 & Tengeru & 1.13 & 1.34 \\
\hline-3.388095 & 36.834787 & $\mathrm{~T} 13$ & Tengeru & 1.27 & 1.53 \\
\hline-3.390375 & 36.867836 & T14 & Tengeru & 2.30 & 5.96 \\
\hline-3.389705 & 36.867828 & $\mathrm{~T} 15$ & Tengeru & 2.19 & 3.13 \\
\hline-3.431228 & 36.851936 & $\mathrm{~T} 17$ & Tengeru & 1.47 & 1.89 \\
\hline-3.441064 & 36.856352 & $\mathrm{~T} 19$ & Tengeru & 1.31 & 1.53 \\
\hline-3.431185 & 36.852054 & T20 & Tengeru & 1.77 & 1.92 \\
\hline-3.445723 & 36.857519 & $\mathrm{~T} 21$ & Tengeru & 2.23 & 3.13 \\
\hline-3.286817 & 36.882092 & M1 & Maji ya Chai & 20.10 & 26.10 \\
\hline-3.297030 & 36.890270 & M2 & Maji ya Chai & 65.20 & 69.01 \\
\hline-3.300897 & 36.882034 & M3 & Maji ya Chai & 14.50 & 17.70 \\
\hline-3.311596 & 36.890981 & M4 & Maji ya Chai & 14.80 & 18.20 \\
\hline-3.327916 & 36.901406 & M5 & Maji ya Chai & 13.80 & 18.00 \\
\hline-3.368379 & 36.896311 & M6 & Maji ya Chai & 11.75 & 16.40 \\
\hline-3.389771 & 36.868054 & M7 & Maji ya Chai & 10.17 & 15.70 \\
\hline-3.348050 & 36.794225 & T8 & Tengeru & 0.92 & 1.14 \\
\hline-3.359968 & 36.799709 & T9 & Tengeru & 1.02 & 1.28 \\
\hline-3.406998 & 36.864624 & T16 & Tengeru & 2.03 & 2.64 \\
\hline-3.429589 & 36.852371 & $\mathrm{~T} 18$ & Tengeru & 1.10 & 1.40 \\
\hline-3.423187 & 36.854269 & T12 & Tengeru & 0.94 & 1.19 \\
\hline-3.313160 & 36.753599 & N1 & Nduruma & 0.84 & 1.33 \\
\hline-3.319881 & 36.744824 & N3 & Nduruma & 1.60 & 1.78 \\
\hline-3.329416 & 36.746495 & $\mathrm{~N} 4$ & Nduruma & 1.13 & 1.34 \\
\hline-3.344450 & 36.744286 & N7 & Nduruma & 0.92 & 1.02 \\
\hline-3.373071 & 36.750155 & N8 & Nduruma & 1.59 & 2.68 \\
\hline-3.402712 & 36.781335 & N9 & Nduruma & 1.59 & 2.16 \\
\hline-3.444499 & 36.793244 & N10 & Nduruma & 1.67 & 2.43 \\
\hline-3.470623 & 36.794341 & N11 & Nduruma & 1.82 & 0.00 \\
\hline-3.491149 & 36.806301 & N12 & Nduruma & 1.71 & 0.00 \\
\hline-3.342963 & 36.753636 & $\mathrm{~N} 2$ & Nduruma & 0.81 & 1.20 \\
\hline-3.352160 & 36.752858 & N5 & Nduruma & 1.39 & 1.69 \\
\hline-3.372934 & 36.751276 & N6 & Nduruma & 2.16 & 2.90 \\
\hline-3.314420 & 36.719588 & Tel & Temi & 1.02 & 1.60 \\
\hline-3.340386 & 36.711055 & $\mathrm{Te} 5$ & Temi & 1.40 & 1.87 \\
\hline-3.360737 & 36.701942 & Te6 & Temi & 1.19 & 1.83 \\
\hline-3.397515 & 36.721275 & $\mathrm{Te} 7$ & Temi & 0.61 & 0.94 \\
\hline-3.370857 & 36.695152 & $\mathrm{Te} 8$ & Temi & 1.26 & 1.83 \\
\hline-3.426367 & 36.697539 & $\mathrm{Te} 9$ & Temi & 1.41 & 2.15 \\
\hline-3.503508 & 36.770893 & Te10 & Temi & 1.54 & 2.68 \\
\hline-3.589528 & 36.809305 & Tell & Temi & 1.36 & 3.38 \\
\hline
\end{tabular}


TABLE 4: Continued.

\begin{tabular}{|c|c|c|c|c|c|}
\hline Latitude & Longitude & Point code & River & $\mathrm{F}^{-}$_wet $(\mathrm{mg} / \mathrm{l})$ & $\mathrm{F}^{-}$dry $(\mathrm{mg} / \mathrm{l})$ \\
\hline-3.282948 & 36.730934 & Te3 & Temi & 1.36 & 1.96 \\
\hline-3.290865 & 36.735081 & $\mathrm{Te} 2$ & Temi & 1.02 & 1.27 \\
\hline-3.423636 & 36.681599 & Te12 & Temi & 1.37 & 2.01 \\
\hline-3.299415 & 36.731638 & $\mathrm{Te} 4$ & Temi & 1.27 & 1.39 \\
\hline
\end{tabular}

TABLE 5: Particle size distribution for ground igneous rocks.

\begin{tabular}{|c|c|c|c|c|c|c|c|c|}
\hline \multirow{2}{*}{ Diameter } & \multicolumn{2}{|c|}{ Solomu } & \multicolumn{2}{|c|}{ Nduruma } & \multicolumn{2}{|c|}{ Maksoro } & \multicolumn{2}{|c|}{ Jamera } \\
\hline & Weight (g) & $\%$ & Weight (g) & $\%$ & Weight (g) & $\%$ & Weight (g) & $\%$ \\
\hline$\geq 2 \mathrm{~mm}$ & 23.9911 & 17.38 & 19.5052 & 14.13 & 21.7323 & 15.75 & 23.5537 & 17.07 \\
\hline $1.5 \mathrm{~mm}$ & 14.7302 & 10.67 & 13.9703 & 10.12 & 10.9429 & 7.93 & 13.1351 & 9.52 \\
\hline $1 \mathrm{~mm}$ & 19.339 & 14.01 & 19.4628 & 14.10 & 17.9295 & 12.99 & 17.8441 & 12.93 \\
\hline $0.35 \mathrm{~mm}$ & 39.5516 & 28.66 & 37.0772 & 26.14 & 34.4105 & 24.94 & 40.1626 & 29.10 \\
\hline $250 \mu \mathrm{m}$ & 5.7149 & 4.14 & 9.0026 & 6.89 & 9.201 & 6.67 & 9.1059 & 6.60 \\
\hline $180 \mu \mathrm{m}$ & 8.9251 & 6.47 & 6.0108 & 4.36 & 8.5363 & 6.19 & 6.5971 & 4.78 \\
\hline $125 \mu \mathrm{m}$ & 14.8566 & 10.77 & 15.9047 & 11.53 & 10.4439 & 7.57 & 17.8368 & 12.93 \\
\hline $90 \mu \mathrm{m}$ & 4.1171 & 2.98 & 11.317 & 8.20 & 14.6206 & 10.59 & 5.0321 & 3.65 \\
\hline $63 \mu \mathrm{m}$ & 3.9996 & 2.90 & 4.0081 & 2.90 & 7.2159 & 5.23 & 3.2776 & 2.38 \\
\hline $45 \mu \mathrm{m}$ & 1.4958 & 1.08 & 0.9102 & 0.66 & 1.7899 & 1.30 & 0.6323 & 0.46 \\
\hline $32 \mu \mathrm{m}$ & 0.5373 & 0.39 & 0.6629 & 0.48 & 0.6107 & 0.44 & 0.4069 & 0.29 \\
\hline $20 \mu \mathrm{m}$ & 0.5885 & 0.43 & 0.4715 & 0.34 & 0.3875 & 0.28 & 0.379 & 0.27 \\
\hline Total & 137.847 & 99.89 & 137.803 & 99.86 & 137.821 & 99.87 & 137.963 & 99.97 \\
\hline
\end{tabular}

The total weight of the sample was $138.0027 \mathrm{~g}$.

This trend was different in Nduruma River in both seasons, whereby $\mathrm{Ca}-\mathrm{Mg}$ and $\mathrm{CO}_{3}{ }^{-}, \mathrm{SO}_{4}{ }^{-}, \mathrm{HCO}_{3}{ }^{-}$, and $\mathrm{Cl}^{-}$were moderate but with low concentrations of $\mathrm{Na}^{+}$and $\mathrm{K}^{+}$and thus the water alkalinity in this river was mainly contributed from hydrolysis of $\mathrm{CO}_{3}{ }^{-}$and $\mathrm{HCO}_{3}{ }^{-}$which increase the levels of $\mathrm{OH}^{-}$as shown in (1) and (2). Therefore, the higher the levels of $\mathrm{CO}_{3}{ }^{-}$and $\mathrm{HCO}_{3}{ }^{-}$, the higher the river $\mathrm{pH}$.

$$
\begin{array}{r}
\mathrm{CO}_{3}{ }^{2-}(\mathrm{aq})+\mathrm{H}_{2} \mathrm{O}(\mathrm{l}) \rightleftharpoons \mathrm{HCO}_{3}^{-}(\mathrm{aq})+\mathrm{OH}^{-}(\mathrm{aq}) \\
K_{b}=2.0 \times 10^{-4} \\
\mathrm{HCO}_{3}{ }^{-}(\mathrm{aq})+\mathrm{H}_{2} \mathrm{O}(\mathrm{l}) \rightleftharpoons \mathrm{H}_{2} \mathrm{CO}_{3}(\mathrm{l})+\mathrm{OH}^{-}(\mathrm{aq}) \\
K_{b}=2.5 \times 10^{-8}
\end{array}
$$

Therefore, the total carbon alkalinity $\left(A_{C}\right)$ of water is practically contributed by hydrolysis of both $\mathrm{CO}_{3}{ }^{-}$and $\mathrm{HCO}_{3}{ }^{-}$ [25].

$$
A_{\mathrm{C}}=\left[\mathrm{HCO}_{3}^{-}\right]+\left[\mathrm{CO}_{3}^{-}\right]
$$

The increased levels of $\mathrm{SO}_{4}{ }^{-}$and $\mathrm{Cl}^{-}$in the downstream can be attributed by the point source pollution from peasant horticultural farming in river banks where some practices use high amounts of fertilizers, herbicides, and pesticides containing such formulations. Generally, $\mathrm{SO}_{4}{ }^{-}$and $\mathrm{Cl}^{-}$were relatively low, which is one of the characteristics for most natural water systems [6].

The levels of $\mathrm{Ca}-\mathrm{Mg}$ in Tengeru River were higher in the dry season than in the wet season with the $\mathrm{Na}^{+}$and $\mathrm{K}^{+}$being low. The anions $\mathrm{SO}_{4}{ }^{2-}$ and $\mathrm{Cl}^{-}$were relatively increasing in the wet compared with the dry season, whereas $\mathrm{CO}_{3}{ }^{2-}$ and $\mathrm{HCO}_{3}{ }^{-}$were low in the wet season compared to the dry season. A similar trend was shown in Maji ya Chai River.

3.1.4. Fluoride Ions Trends. The fluoride levels in various points of the respective rivers are indicated in Table 4. They are further summarized with geostatistical analysis and mapped as shown in Figures 4(a) and 4(b). The $\mathrm{pH}$ spatial distribution reflecting the $\mathrm{pH}$ dependency for fluoride levels in water is shown in Figures 5(a) and 5(b). The study shows $\mathrm{pH}$ to play a great role in the availability of fluoride ions in water. The lowest average fluoride level of $0.24 \pm 0.02 \mathrm{mg} / \mathrm{l}$ was recorded during the wet season in Makitengwe stream which is a tributary subcatchment of Tengeru River. In the same season, the highest average fluoride level of $65.20 \pm 0.26 \mathrm{mg} / \mathrm{l}$ was measured in Maji ya Chai River (Figure 4(a)). This river is located at Arusha National Park (ANP) and is used as one of the major drinking water sources for wildlife.

The lowest average fluoride level in the dry season was recorded in Kijenge stream in Temi River with an average level of $0.94 \pm 0.07 \mathrm{mg} / \mathrm{l}$, whereas the highest average level of $69.01 \pm 0.21 \mathrm{mg} / \mathrm{l}$ was recorded in Maji ya Chai River (Figure 4(b)). The increase in fluoride levels in the dry season may be attributed to the absence of runoff to the river which may cause dilutions, and hence in that period the river flow is mainly from groundwater (old water) containing more fluoride ions. It should be noted that the groundwater mixing with surface water has enough time for interaction with 
TABLE 6: The $\mathrm{pH}$ dependence of fluoride leaching from igneous rocks at $25^{\circ} \mathrm{C}$.

\begin{tabular}{|c|c|c|c|c|c|c|c|}
\hline \multicolumn{2}{|c|}{ Tengeru (Solomu) } & \multicolumn{2}{|c|}{ Nduruma } & \multicolumn{2}{|c|}{ Maksoro (M1) } & \multicolumn{2}{|c|}{ Jamera (M2) } \\
\hline $\mathrm{pH}$ & ${ }^{*}\left[\mathrm{~F}^{-}\right]$ & $\mathrm{pH}$ & ${ }^{*}\left[\mathrm{~F}^{-}\right]$ & $\mathrm{pH}$ & ${ }^{*}\left[\mathrm{~F}^{-}\right]$ & $\mathrm{pH}$ & ${ }^{*}\left[\mathrm{~F}^{-}\right]$ \\
\hline 3.72 & 0.26 & 3.82 & 0.28 & 3.85 & 0.43 & 3.75 & 1.28 \\
\hline 4.20 & 0.29 & 4.17 & 0.31 & 4.32 & 0.49 & 4.00 & 1.44 \\
\hline 5.34 & 0.33 & 5.44 & 0.72 & 5.63 & 0.46 & 4.05 & 1.77 \\
\hline 6.95 & 1.37 & 6.37 & 0.97 & 6.76 & 0.64 & 4.33 & 2.15 \\
\hline 7.22 & 2.83 & 7.47 & 1.74 & 7.49 & 0.68 & 4.6 & 2.15 \\
\hline 8.51 & 3.86 & 8.82 & 2.73 & 8.03 & 1.21 & 5.69 & 2.17 \\
\hline 9.72 & 3.95 & 9.49 & 2.53 & 9.17 & 3.71 & 6.24 & 2.28 \\
\hline 10.21 & 3.95 & 10.73 & 2.53 & 10.6 & 5.95 & 7.07 & 2.79 \\
\hline 11.94 & 3.94 & 10.99 & 2.53 & 11.3 & 6.20 & 8.25 & 9.05 \\
\hline 12.64 & 3.94 & 12.01 & 2.53 & 12.34 & 26.60 & 9.48 & 10.3 \\
\hline 13.08 & 3.94 & 13.37 & 2.53 & 13.17 & 26.85 & 10.85 & 18.75 \\
\hline 13.55 & 3.94 & - & - & 13. 35 & 26.89 & 11.07 & 29.55 \\
\hline- & - & - & - & - & - & 12.61 & 72.5 \\
\hline- & - & - & - & - & - & 12.79 & 73.95 \\
\hline- & - & - & - & - & - & 13.17 & 74.3 \\
\hline
\end{tabular}

${ }^{*}\left[\mathrm{~F}^{-}\right]$in $\mathrm{mg} / \mathrm{l}$.

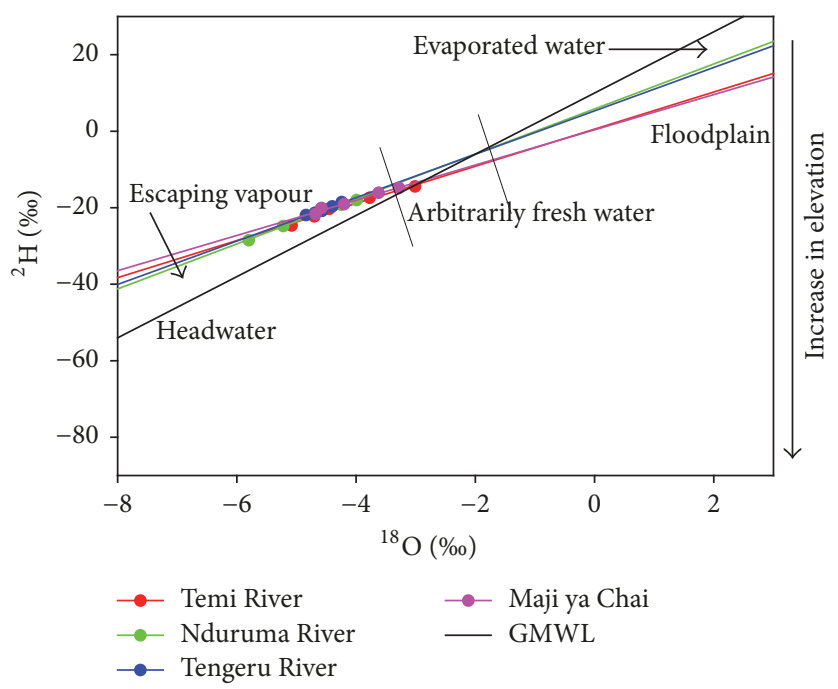

Figure 2: A plot of $\delta^{2} \mathrm{H}$ versus $\delta^{18} \mathrm{O}$ indicating an increase in evaporation downstream.

fluoride containing rocks which allow dissolution of more fluoride ions in it.

The headwater environment of the three rivers (Temi, Nduruma, and Tengeru) showed low a fluoride level of $<4.0 \mathrm{mg} / \mathrm{l}$ which is in line with the standards recommended by WHO and TBS except for the headwater environment of Maji ya Chai River which had extremely high fluoride levels of up to $69.0 \mathrm{mg} \pm 0.38 \mathrm{mg} / \mathrm{l}$. Low fluoride levels in the three rivers (Temi, Nduruma, and Tengeru) in both seasons are mainly caused by low fluoride composition in the phonolite feldspar rocks which predominate at the upstream main catchment areas of these rivers, thus discharging low fluorides amount in water. Another general trend of interest is observed on the spatial distribution of fluoride at the headwater where fluorides were shown to increase from the southwestern part to the southeastern part $(0.24 \mathrm{mg} / \mathrm{l}$ to $69.01 \mathrm{mg} / \mathrm{l}$ ) with respect to Mount Meru. This trend can be explained by the fact that its headwater from the southwestern part is at a high altitude with low temperature, where the lower the temperature, the lower the dissolution rate of fluoride from rocks. Also, the aquifer lithology at such high altitude is predominantly phonolite which is characterized by low fluoride contents [19]. The headwater source in Maji ya Chai River is from lowland (foothills of Mount Meru) in the southeastern region of the mountain characterized by relatively high temperature incidence due to low canopy cover, and its aquifer lithology is basalt which is characterized by high fluoride levels (Table 6) [19]. All these features favor high fluoride contents in water of the river. 


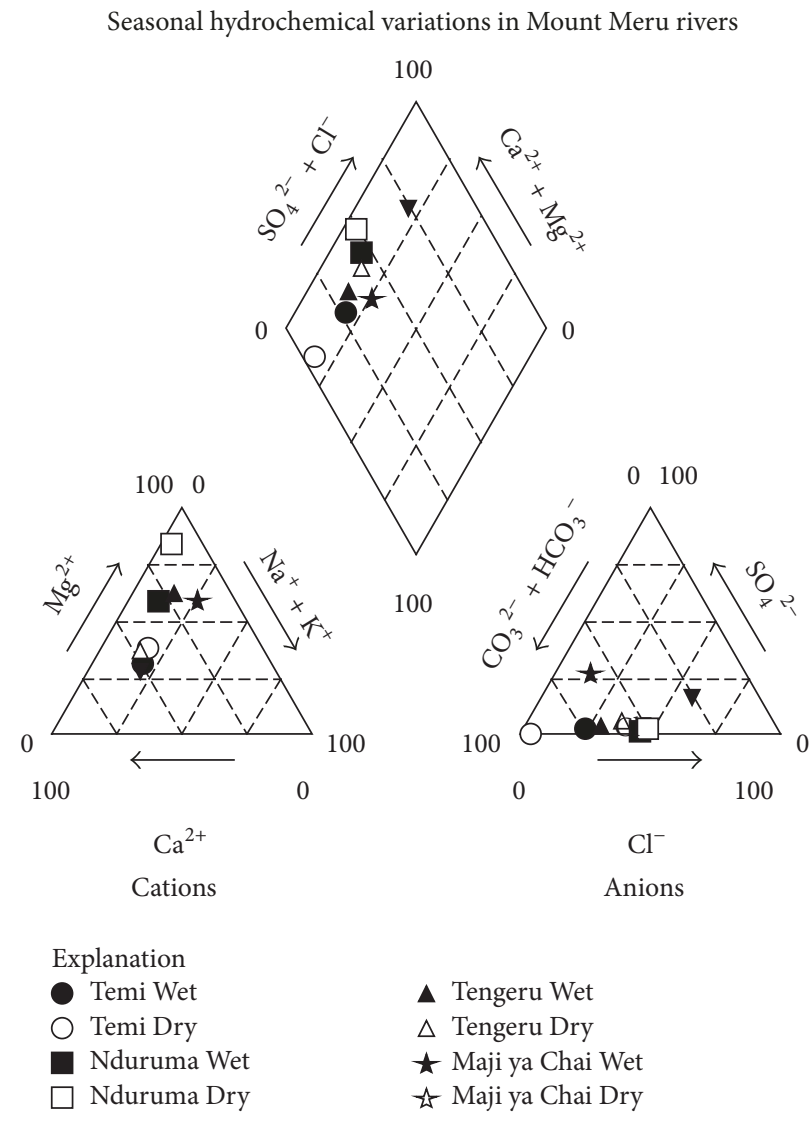

FIGURE 3: Piper diagrams for distribution of major cations and anions in the four rivers.

The abovementioned trends are evidenced by the laboratory experiments for fluoride leaching from rocks collected at Nduruma, Tengeru (Solomu stream), Maksoro, and Jamera (M2) (Maji ya Chai) Rivers catchment banks as shown in Table 6. In this experiment, the rocks collected from the three rivers have been shown to release a low amount of fluoride ions at various $\mathrm{pH}$ with further negative response even at high alkaline environment which favors fluoride leaching. The low fluoride leaching in these rocks even at highly alkaline environment is evidence of low fluoride amounts contained in rocks. More experiments from the high fluoride containing rocks (collected from basalt rocks of Jamera) show high amounts of fluoride leaching which acquires its maximum levels in the alkaline environment with no further changes upon increase of its $\mathrm{pH}$. At such point, complete fluoride leaching from the rocks is assumed (Table 6, Figure 7).

In addition to the above findings, it was observed that the average fluoride levels in the three rivers increase downstream up to $3.38 \pm 0.16 \mathrm{mg} / \mathrm{l}$ at the floodplain in Temi River. Such observed trend does not happen at Maji ya Chai River where the fluoride levels were shown to decrease downstream. This is caused by dilutions from Ngurdoto and Shoripanga streams feeding to the main river in between with averaged fluoride concentration of $3.32 \pm 0.26 \mathrm{mg} / \mathrm{l}$ and $4.21 \pm 0.17 \mathrm{mg} / \mathrm{l}$, respectively. Also, the extremely high difference in fluoride levels in the headwater environment of Maji ya Chai compared to other sampling areas of the same river indicates the main point source pollution of fluoride in the river which has been identified at Jamera (Figure 4). The statistical tests showed good positive correlations $(r)$ in the dry season between fluoride levels and $\mathrm{pH}$ and EC together with temperature simply because there were only groundwater (old water) recharges with the absence of runoff which may increase dilutions of river water at various rates.

3.2. Fluoride Distribution in Temi River. Fluoride levels in Temi River increased from the headwater downstream to the floodplain in both wet and dry seasons. The minimum average fluoride level was in the upstream headwater region of the river with average values of $1.02 \pm 0.01 \mathrm{mg} / \mathrm{l}$ and 1.27 $\pm 0.07 \mathrm{mg} / \mathrm{l}$ during wet and dry seasons, respectively. The maximum level was measured at the floodplain with the average values of $1.54 \pm 0.03 \mathrm{mg} / \mathrm{l}$ and $2.68 \pm 0.02 \mathrm{mg} / \mathrm{l}$ in wet and dry seasons, respectively (Figures 4(a) and 4(b)). Furthermore, the headwater and middle regions of the river had fluoride levels lower than the WHO permissible levels for drinking water of $1.50 \mathrm{mg} / \mathrm{l}$ [3], whereas the remaining part had fluoride levels higher than WHO permissible standards but within the TBS maximum permissible levels of $4.0 \mathrm{mg} / \mathrm{l}$ in both seasons (Figures 4(a) and 4(b)) [2]. Higher fluoride levels in the floodplain can be explained by low water velocities which in turn increase the interaction time of water with basalt aquifers containing high fluoride element. 


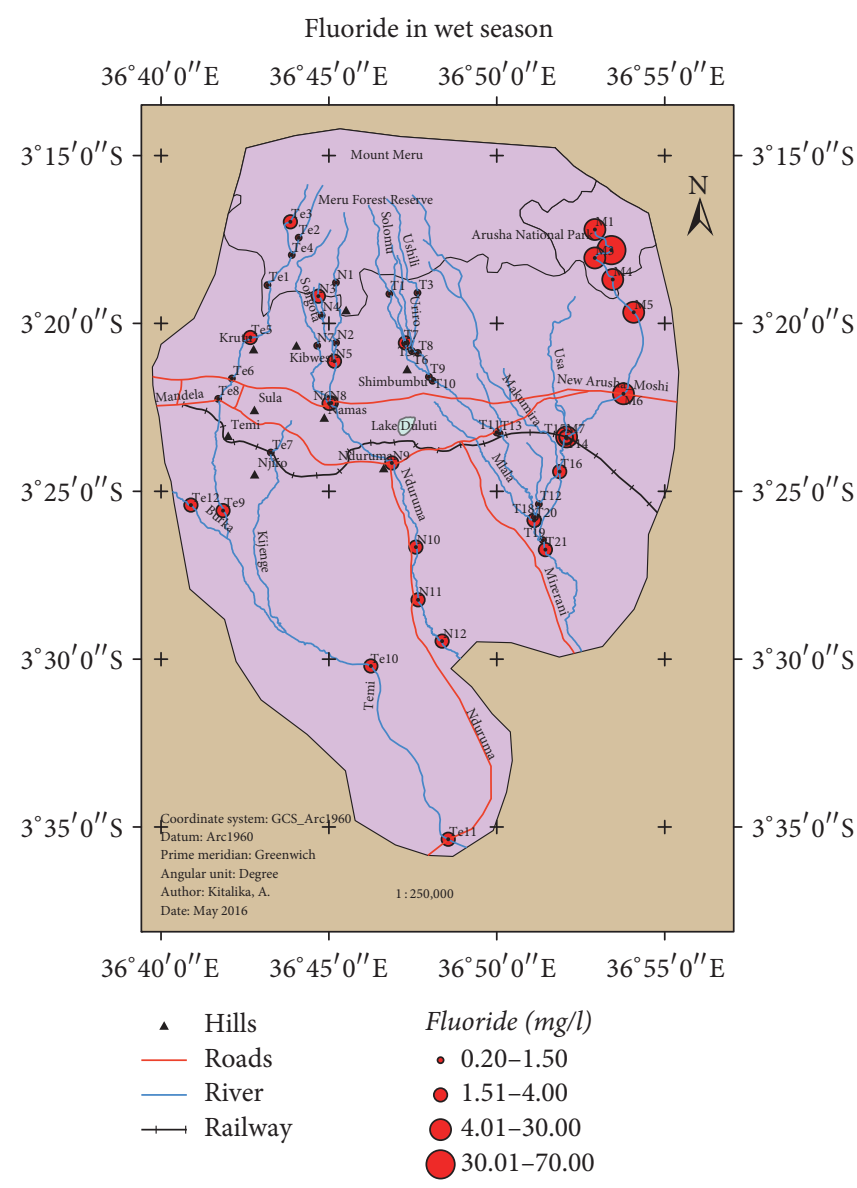

(a)

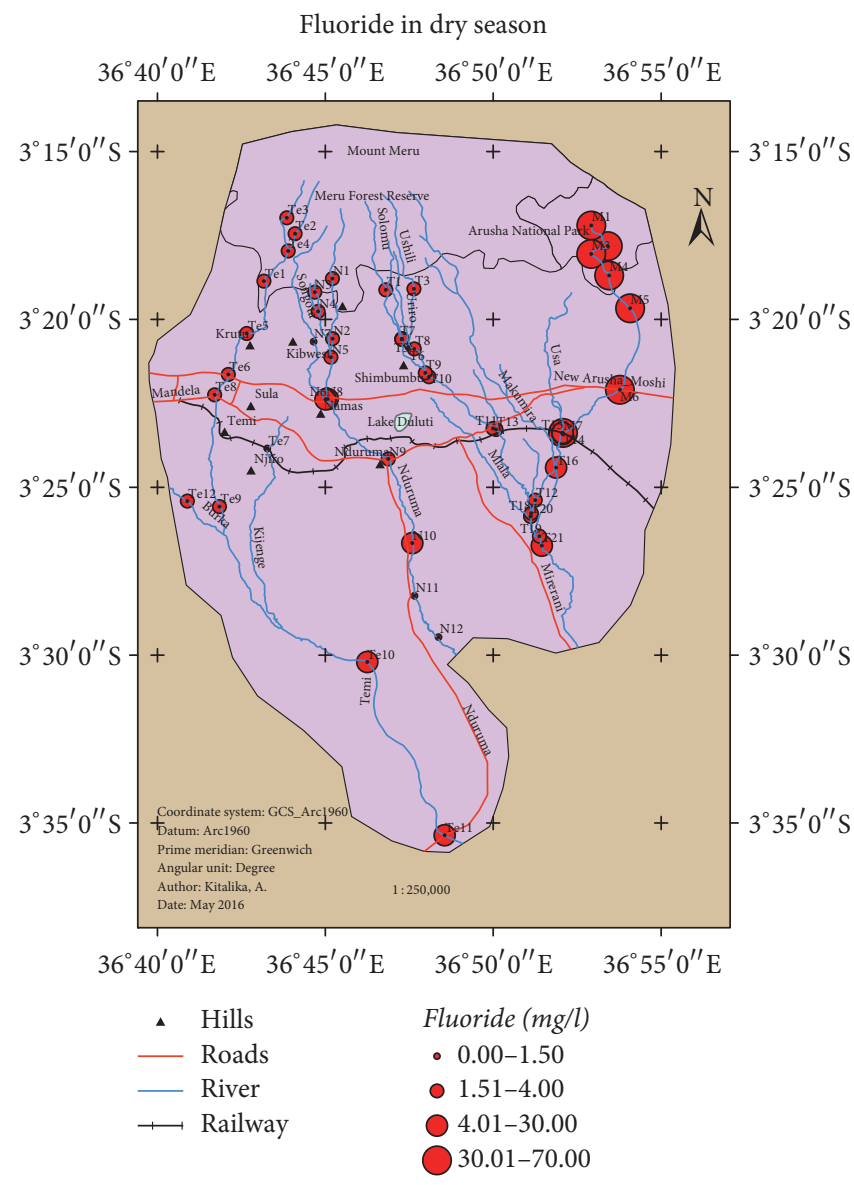

(b)

FIGURE 4: Fluoride variation in wet (a) and dry (b) seasons.

Together with this, the slightly alkaline condition in the floodplain favors the availability of fluorides in water as suggested by Saxena and Ahmed in their experiments [26].

In addition to the increase in fluoride levels downstream to the floodplain, the study shows a strong positive Pearson correlation of fluoride levels between wet and dry seasons $(r=0.87, n=13, p \leq 0.005)$ which suggest common pollution sources between seasons (Figure 6(a)). Using the two-sample $t$-test for unequal variance, the means of fluoride levels were significantly different between seasons, and thus the fluoride levels were significantly higher in the dry season than in the wet season $(n=13, p \leq 0.001)$. The higher fluoride levels in the dry season can be explained by the river recharge from groundwater containing high fluoride levels as the major source without dilutions from runoff. Increase in $\mathrm{pH}$ showed a strong positive Pearson correlation with fluoride levels $(r=0.9, n=13, p \leq 0.0001)$ (Figure 7(a)). Similar correlation trends have been shown by Saxena and Ahmad in their study on water-rock interaction on dissolution of fluoride containing feldspar rocks [26].

3.3. Fluoride Distribution in Nduruma River. Nduruma River had fluoride levels of $0.84 \pm 0.05 \mathrm{mg} / \mathrm{l}$ to $2.16 \pm 0.01 \mathrm{mg} / \mathrm{l}$ and $1.02 \pm 0.02 \mathrm{mg} / \mathrm{l}$ to $2.90 \pm 0.05 \mathrm{mg} / \mathrm{l}$ during wet and dry seasons, respectively. The headwater and middle regions had fluoride levels within the WHO maximum permissible levels while the rest of the region was within the TBS standards (Figures 4(a) and 4(b)). Also, the fluoride concentrations in this river were shown to increase from the upstream to the floodplain, in favor of the increase of some its physicochemical properties including water temperature, $\mathrm{pH}$, and EC. These good trends were much more pronounced in the dry season, depicting that the river water recharge was mainly from groundwater (old water) which had good interaction time with rocks containing salts. The very strong positive correlation in fluoride levels between wet and dry seasons $(r=0.9, n=12, p \leq 0.0002)$ also suggests the common pollutant sources in the two seasons (Figure 6(b)).

The minimum and maximum average water temperature in the wet season were $12.01 \pm 0.06^{\circ} \mathrm{C}$ and $20.48 \pm 0.04^{\circ} \mathrm{C}$, respectively, whereas during the dry season, the minimum and maximum average water temperature were $12.61 \pm 0.03^{\circ} \mathrm{C}$ and $24.32 \pm 0.07^{\circ} \mathrm{C}$, respectively. While the $\mathrm{pH}$ trends in the wet season showed many irregularities due to various external factors such as surface runoffs, the minimum and maximum average $\mathrm{pH}$ ranges were from $7.63 \pm 0.01$ to 9.4 


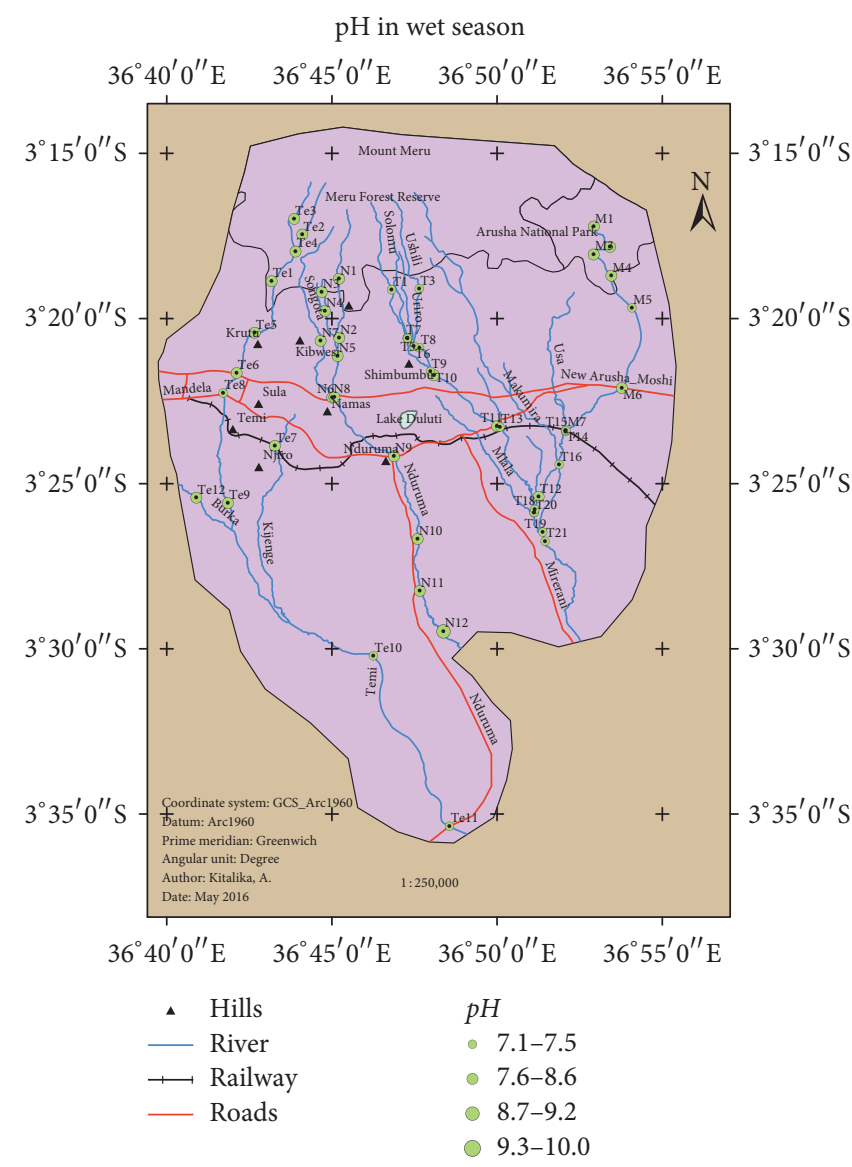

(a)

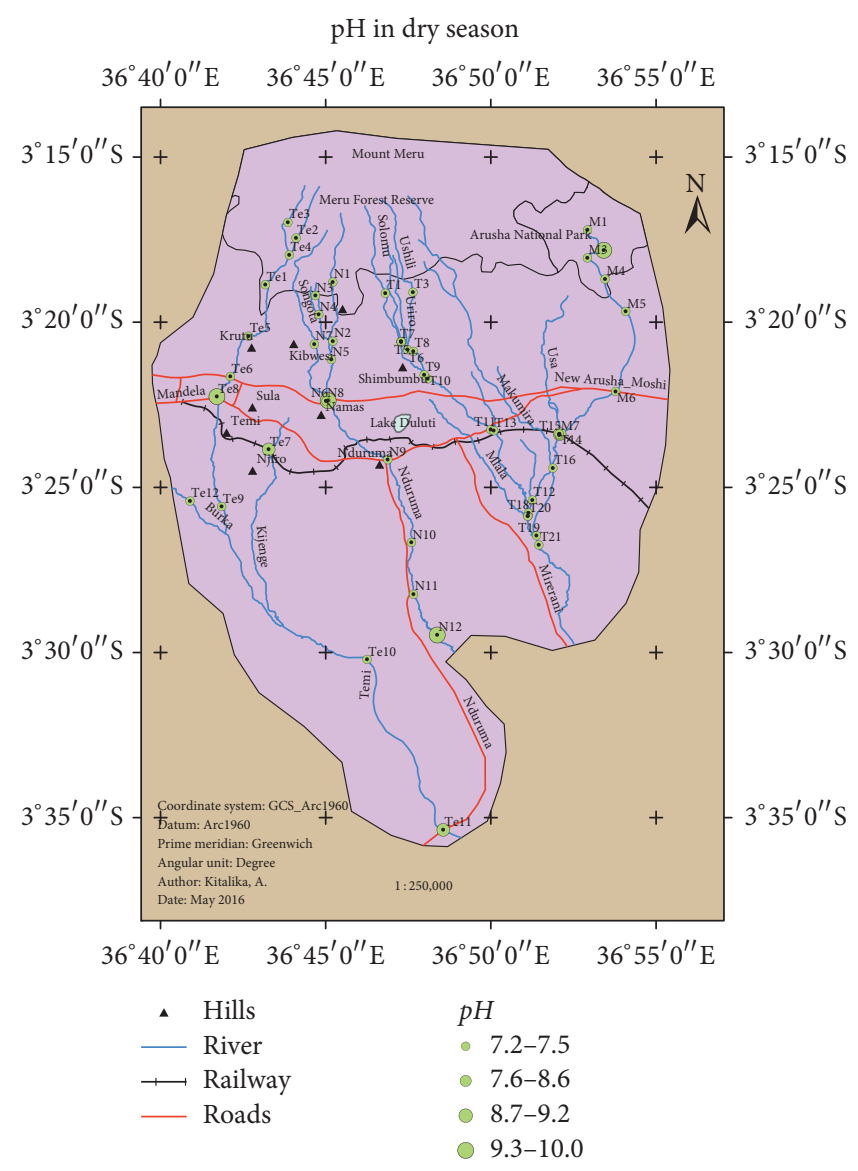

(b)

FIGURE 5: Water pH in wet (a) and dry (b) seasons.

\pm 0.03 and $7.4 \pm 0.08$ to $9.9 \pm 0.01$ for wet and dry seasons, respectively. A strong positive correlation between fluoride levels and $\mathrm{pH}$ in the dry season $(r=0.93, n=12, p \leq 0.02)$ suggests that the increase in water $\mathrm{pH}$ increases the ability of dissolution of fluoride containing rocks in water (Figure 7(b)) [26], hence an increase in fluoride ions in water. Also, the mean fluoride levels between seasons were significantly not different $(p \leq 0.7, n=12)$, suggesting that seasonal dilution in this river had no significant impact on the fluoride availability in water.

3.4. Fluoride Distribution in Tengeru River. The fluoride levels in this river were shown to fluctuate as a result of dilution from inputs of several tributaries such as Ngare Sero and Malala which had very low fluoride levels. The headwater of this river showed lower values than the WHO standards while the floodplain showed higher values due to effects from Maji ya Chai River (Figures 4(a) and 4(b)). Despite such fluctuations, fluoride levels in this river increased when the confluence between Usa River and Maji ya Chai contributed its water to form the main Kikuletwa River. Higher levels in this downstream were caused by Maji ya Chai River which had the highest fluoride levels among the studied rivers. Despite their low levels, the wet season had lower levels than the dry season such that the minimum average levels in this river were $0.24 \pm 0.03 \mathrm{mg} / \mathrm{l}$ and $0.97 \pm 0.01 \mathrm{mg} / \mathrm{l}$ whereas its average maximum levels were $2.23 \pm 0.01 \mathrm{mg} / \mathrm{l}$ and $3.13 \pm$ $0.03 \mathrm{mg} / \mathrm{l}$ for wet and dry seasons, respectively. In addition, the higher values in the floodplain did not exceed the TBS standards of $4.0 \mathrm{mg} / \mathrm{l}$. Generally, this river showed the lowest fluoride levels in the study area. Water temperature in this river had slight changes due to high canopy cover in its riparian environment throughout, whereby the minimum temperatures were $14.00 \pm 0.02^{\circ} \mathrm{C}$ and $15.00 \pm 0.01^{\circ} \mathrm{C}$ with its maximum temperature being $18.71 \pm 0.02^{\circ} \mathrm{C}$ and $21.00 \pm$ $0.04^{\circ} \mathrm{C}$ for wet and dry seasons, respectively.

The statistical test showed a very strong positive correlation in fluoride levels between the two seasons $(r=0.9, n=$ $21, p \leq 0.0002$ ), suggesting a common source of pollutant in the two seasons (Figure 6(c)). In addition to this, a very weak positive correlation $(r=0.4, n=21, p \leq 0.4)$ was shown between fluoride levels and $\mathrm{pH}$ during the dry season, suggesting that the slight changes in $\mathrm{pH}$ had no significant effect on fluoride variations (Figure $7(\mathrm{c})$ ). Together with these, their mean fluoride levels between seasons were shown to be significantly different $(n=21, p=0.02)$, indicating that water from rainfall had a significant effect on the water quality changes and the contributing water in the dry season was mainly from groundwater recharge. 


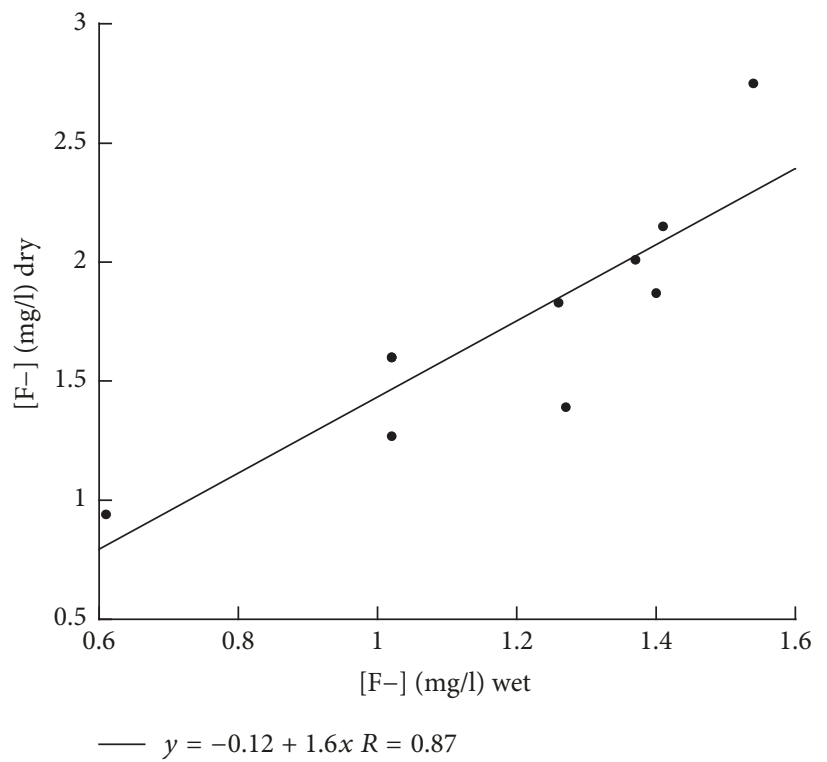

(a)

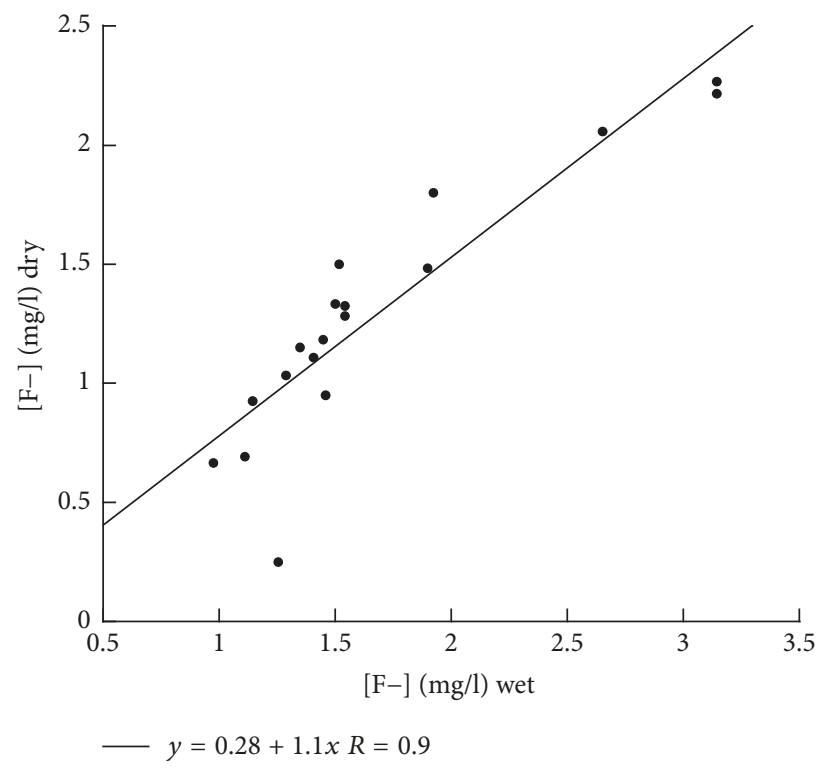

(c)

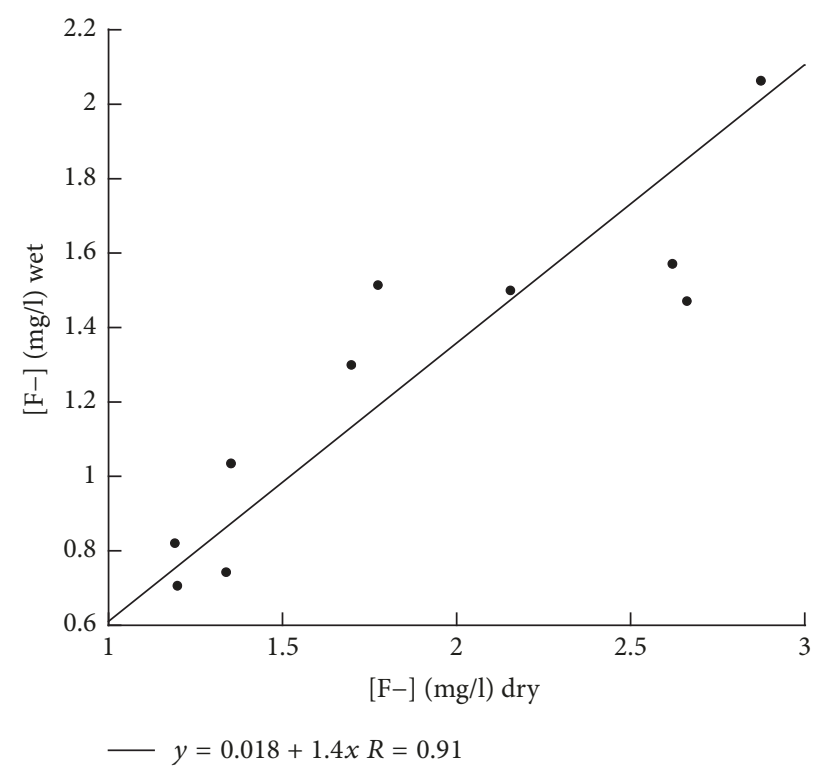

(b)

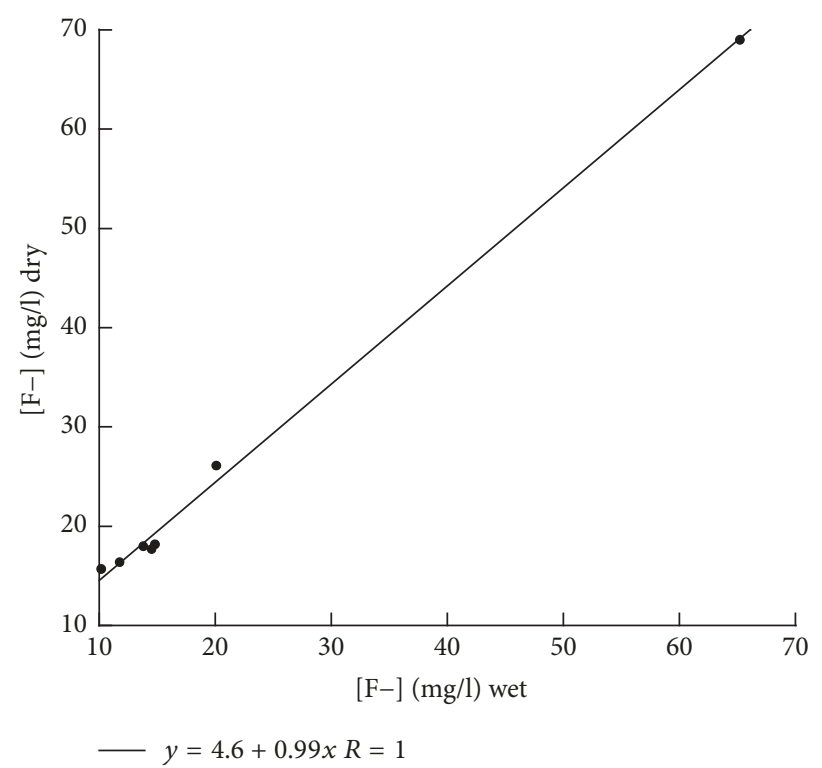

(d)

FIgURE 6: Correlation of fluoride between wet and dry seasons in (a) Temi, (b) Nduruma, (c) Tengeru, and (d) Maji ya Chai.

3.5. Fluoride Distribution in Maji Ya Chai River. During the wet season, the average fluoride levels were between $11.75 \pm 0.70 \mathrm{mg} / \mathrm{l}$ and $65.20 \pm 0.03 \mathrm{mg} / \mathrm{l}$ whereas the minimum average levels in the dry season ranged from $16.40 \pm$ $0.05 \mathrm{mg} / \mathrm{l}$ to $69.01 \pm 0.03 \mathrm{mg} / \mathrm{l}$, both highest being recorded in the headwater at Jamera (M2). A similar concentration of $59 \mathrm{mg} / \mathrm{l}-68 \mathrm{mg} / \mathrm{l}$ fluoride was recorded in the past five years in the nearby hydrothermal spring feeding its water in Engare Nanyuki River which is a lowland river with respect to Maji ya Chai River [19]. These similarities may entail common fluoride containing rock in all rivers around the area. Interestingly, Jamera (M2) was discovered to be the main point source for fluoride ions in this river and contains the highest fluoride concentration among others. This area is characterized by high fluoride levels in its river bank rocks (Table 6) and highest $\mathrm{pH}(9.6 \pm 0.02)$ among all measurements recorded, creating a good alkaline environment which favors high fluoride dissolution from rocks compared to other areas. Also, this area is characterized by very low water velocity of $0.27 \mathrm{~m} / \mathrm{s}$ which favors a good interaction time of water with fluoride containing rocks.

Low fluoride concentration in the downstream of Maji ya Chai River is due to dilutions from springs contributing water to the main river which have a low fluoride level range of $1.62 \pm 0.01 \mathrm{mg} / \mathrm{l}$ and $3.01 \pm 0.04 \mathrm{mg} / \mathrm{l}$ in the wet season and $3.32 \pm 0.26 \mathrm{mg} / \mathrm{l}$ and $4.21 \pm 0.17 \mathrm{mg} / \mathrm{l}$ in the dry seasons, 


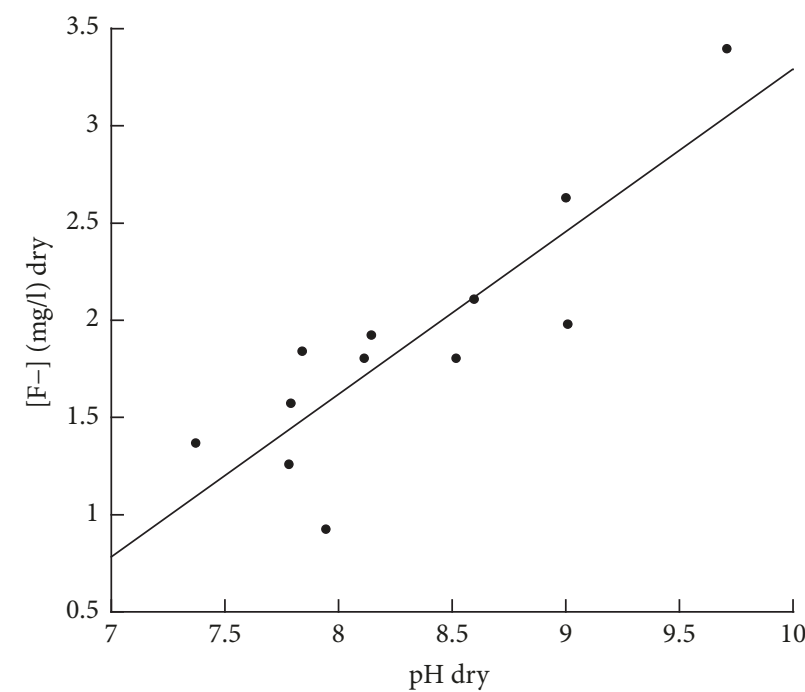

$-y=-5.1+0.84 x R=0.86$

(a)

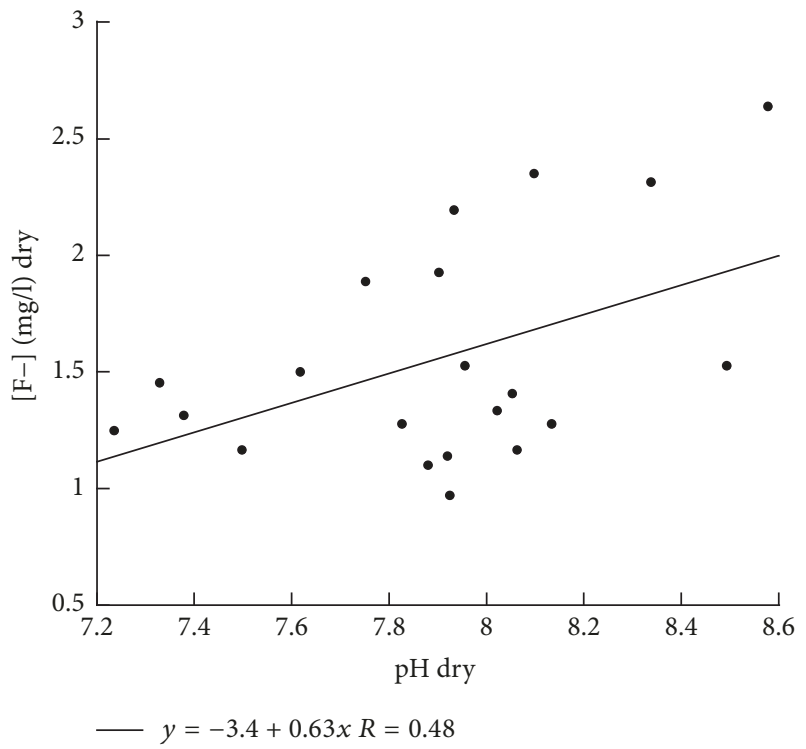

(c)

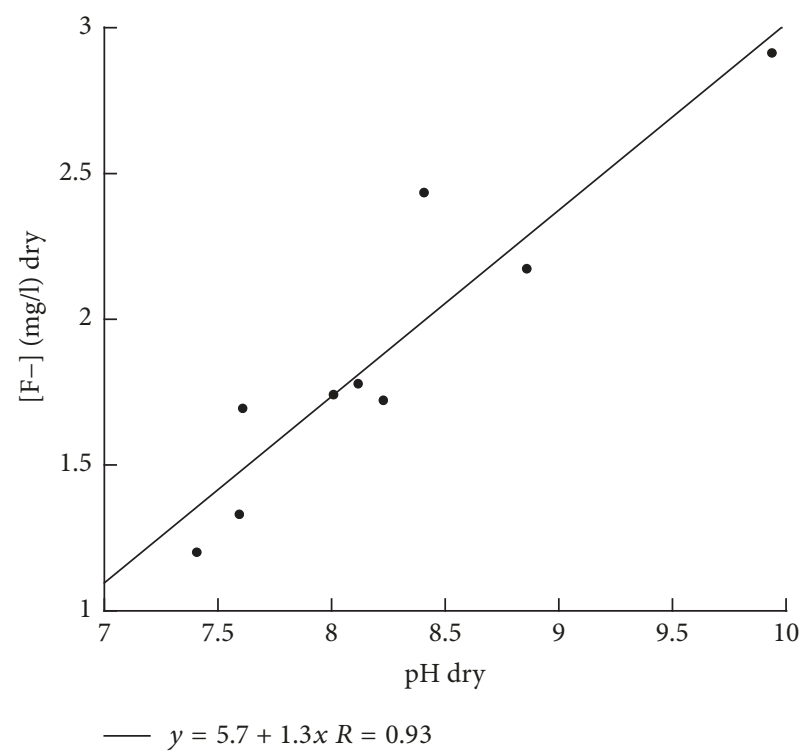

(b)

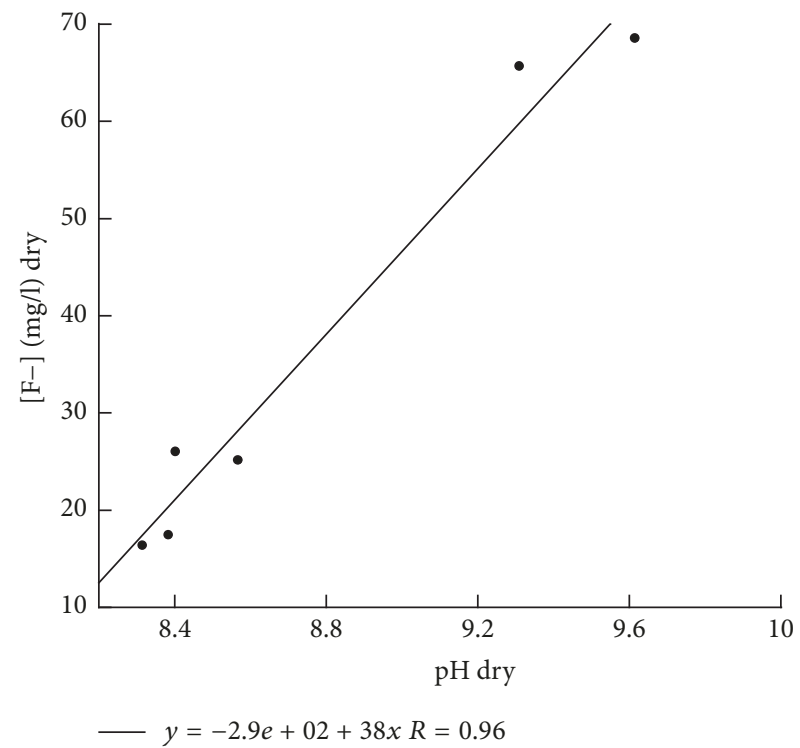

(d)

Figure 7: Correlation of fluoride with pH for the dry season in (a) Temi, (b) Nduruma, (c) Tengeru, and (d) Maji ya Chai.

namely, Ngurdoto and Shoripanga springs, respectively. The contributed values are quite lower than minimum levels observed in the two seasons of the main river. In addition, waters from this river had very high EC compared to other nearby rivers, indicating that the river contains more soluble salts. The area noted with the highest fluorides and $\mathrm{pH}$ also had the highest EC $(1958 \pm 0.7 \mu \mathrm{S} / \mathrm{cm}$ and $1187 \pm 0.3 \mu \mathrm{S} / \mathrm{cm})$ with their average minimum values being $896 \pm 0.3 \mu \mathrm{S} / \mathrm{cm}$ and $791 \pm 0.6 \mu \mathrm{S} / \mathrm{cm}$ in dry and wet seasons, respectively. This good $\mathrm{pH}$ dependence correlation was previously shown by Saxena and Ahmed in their experiment on $\mathrm{pH}$ rock interaction in dissolution of fluoride containing granitic rock, and it was found that the $\mathrm{pH}$ range of 7.6-8.6 favors the rock dissolution [26].
The comparison of fluoride levels between seasons indicated a very strong positive correlation between seasons $(r=$ $1, n=7, p \leq 0.002)$, indicating that the pollutant originates from a common source (Figure 6(d)). Also, a very strong positive correlation $(r=0.9, n=7, p \leq 0.005)$ was observed between the fluoride levels and $\mathrm{pH}$ in the dry season, an indication that dissolution of fluoride rocks is a function of $\mathrm{pH}$ (Figure 7(d)) [20, 26].

3.6. The pH Dependence in Fluoride Leaching from Rocks. The plot of $\mathrm{pH}$ against $\left[\mathrm{F}^{-}\right]$from Table 6 was done to assess the relationship between the two parameters. The study from Figure 8 shows three phases of rock leaching whereby Phase I 


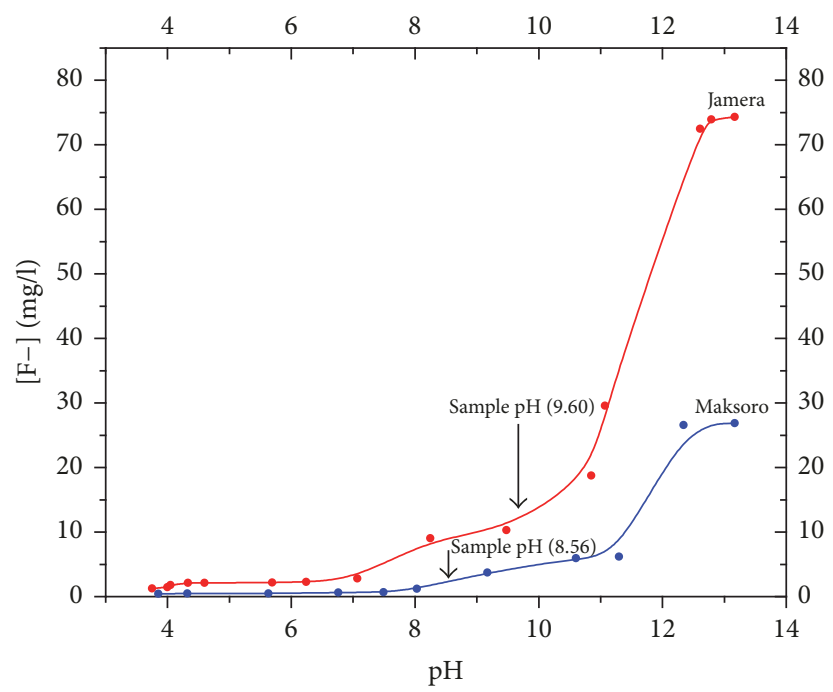

FIGURE 8: $\mathrm{pH}$ dependent fluoride leaching in feldspar-quartz igneous rock at $25^{\circ} \mathrm{C}$.

involves $\mathrm{pH}$ below 7.6 where there is little response of fluoride leaching until neutral $\mathrm{pH}$. Phase II involves the $\mathrm{pH}$ range of 7.6 to 11 where there is a good response to the increase of alkalinity $(\mathrm{pH})$ with fluoride leaching. Phase III which starts at $\mathrm{pH} 11$ shows a quick response in fluoride leaching in the rock. The $\mathrm{pH}$ of water samples ranged from 7.12 to 9.90 which is slightly above neutral to alkaline, thus all corresponding to Phase II in our experiment. These results are supported by Saxena and Ahmad in a similar study with granite rock which showed good response in $\mathrm{pH}$ 7.6-8.8 [26].

At low $\mathrm{pH}$, slow fluoride leaching is expected from rocks in the environment. However, there were some water samples which had high $\mathrm{pH}$ with a lower fluoride concentration than expected. Such results depict an important message to scientists that the availability of fluoride ions in water depends mainly on the nature of rocks that they interact with, whether they contain fluoride or not, and also their response to leaching under favorable conditions. From this experiment, it was found that the amount of fluoride in rocks is another major limiting factor for the presence of this pollutant in water, whose availability is favored by alkaline environments.

3.6.1. The Role of $\mathrm{OH}^{-}$in Fluoride Leaching from Rocks. The alkaline environment associated with fluoride leaching occurs as a result of several reactions, including the reactions between fluorite $\left(\mathrm{CaF}_{2}\right)$ and $\mathrm{HCO}_{3}{ }^{-}$which release fluoride ions (see (4)) [20].

$$
\begin{aligned}
& \mathrm{CaF}_{2}(\mathrm{~s})+2 \mathrm{HCO}_{3}{ }^{-}(\mathrm{aq}) \\
& \quad \longrightarrow \mathrm{CaCO}_{3}(\mathrm{~s})+2 \mathrm{~F}^{-}(\mathrm{aq})+\mathrm{CO}_{2}(\mathrm{l})+\mathrm{H}_{2} \mathrm{O}(\mathrm{l})
\end{aligned}
$$

Also, the carbonate ions present in the aqueous solution increase the alkalinity of water through reaction (1). When $\mathrm{CO}_{2}$ (g) (from reaction (4) and atmospheric) is dissolved in water, it gives carbonic acid (reaction (5)), where in turn the acid decreases the $\mathrm{pH}$ of water due to increased $\mathrm{H}^{+}$(reaction
(6)). This process is very minimum due to the low solubility of $\mathrm{CO}_{2}(\mathrm{~g})$ in water and the resulting acid is weak.

$$
\begin{aligned}
& \mathrm{CO}_{2}(\mathrm{~g})+\mathrm{H}_{2} \mathrm{O}(\mathrm{l}) \longrightarrow \mathrm{H}_{2} \mathrm{CO}_{3}(\mathrm{aq}) \\
& \mathrm{H}_{2} \mathrm{CO}_{3}(\mathrm{aq}) \rightleftharpoons \mathrm{HCO}_{3}{ }^{-}(\mathrm{aq})+\mathrm{H}^{+}(\mathrm{aq}) \\
& K_{a}=2.5 \times 10^{-4}
\end{aligned}
$$

The formed $\mathrm{HCO}_{3}{ }^{-}$from (6) accelerates further the dissolution of $\mathrm{CaF}_{2}$ (s) rock to release more $\mathrm{F}^{-}$(aq.). However, in this experiment, since the fluoride containing rock is a feldspar, at low $\mathrm{pH}$ (acidic), alumina surfaces can be hydrogenated into a neutrally charged species which also gives free aluminum ions (reaction (7)) [27].

$$
\begin{array}{ll}
\equiv \mathrm{Si}-\mathrm{O} \backslash & \equiv \mathrm{Si}-\mathrm{OH} \\
\equiv \mathrm{Si}-\mathrm{O}-\mathrm{Al}-\mathrm{OH}_{2}+3 \mathrm{H}^{+}(\mathrm{aq}) \longrightarrow \mathrm{Al}^{3+}(\mathrm{aq})+ & \equiv \mathrm{Si}-\mathrm{OH}+\mathrm{H}_{2} \mathrm{O} \\
& \equiv \mathrm{Si}-\mathrm{O}^{-}
\end{array}
$$

Thus, every one $\mathrm{Al}^{3+}$ will polarize three water molecules to give three $\mathrm{H}^{+}$which increase the acidity of water (see (8)). This reaction reduces the free fluoride ions in solution.

$$
\mathrm{Al}^{3+}(\mathrm{aq})+3 \mathrm{H}_{2} \mathrm{O}(\mathrm{l}) \longrightarrow \mathrm{Al}(\mathrm{OH})_{3}(\mathrm{aq})+3 \mathrm{H}^{+}(\mathrm{aq})
$$

Since $\mathrm{CO}_{3}^{-}$did not react with $\mathrm{CaF}_{2}$ previously, it was hydrolyzed in water to give more $\mathrm{OH}^{-}$which is consumed by $\mathrm{H}^{+}$in (8), increasing the dissolution of feldspar surfaces containing fluoride, which in turn further exposes the new surfaces from feldspar to the reaction since more $\mathrm{H}^{+}$is consumed (Phase II responses). This decreases the resistance of igneous rock against weathering, exposing more free fluorides in water (Phase III).

Therefore, the different phases in the rock dissolution are caused by a mixture of reactions and nature of the rock; when these processes actively work in a particular environment, their collective effect becomes substantial. 


\section{Conclusions}

The present study shows that the fluoride levels in all rivers were spatially distributed such that the levels in the pristine (headwater) regions of Temi, Nduruma, and Tengeru rivers were lower than what WHO and TBS recommended. The spatial variation of fluoride in rivers is a function of rock composition (the amount of fluoride present in it) and several other chemical reactions which lead to changes in the $\mathrm{pH}$ of the environment. Moreover, interaction of groundwater and surface water patterns and external inputs such as surface runoff, salinity, and climate change, which affects the water temperature, also govern its availability. Also, these findings show the importance of environmental conservation in water sources or catchment areas in which well conserved environments reduce the rates of several chemical reactions due to low water temperature such that an increase in water temperature alters the natural water composition due to the increased rate of chemical reactions. The availability of fluoride in water is highly affected by $\mathrm{pH}$ such that it is more favored in alkaline environments. However, nonconserved floodplains have shown higher levels of the pollutant as they are catalyzed by external factors such as high water temperature and high water-rock interaction time due to low water velocity and its lithology. An exception is observed in Maji ya Chai River where the pristine (headwater) environment showed elevated fluoride levels, which is basically caused by its high fluoride in fluoride bearing rocks in the river banks, in which its dissolution is supported by the high alkaline environment in the river. Also, this study is of great help to different authorities as it enlightens some of the best practices of the catchment area and its management which can also minimize the cost for water processing.

\section{Conflicts of Interest}

The authors declare that they have no conflicts of interest.

\section{Acknowledgments}

The authors would like to acknowledge the Tanzanian Government for their financial assistance and the VILR-OUS Project for providing transport and analytical instruments in this entire study.

\section{References}

[1] M. C. Lathman and P. Grech, "The effects of excessive fluoride intake.," American Journal of Public Health, vol. 57, no. 4, pp. 651-660, 1967.

[2] R. B. Cattell, "The scree test for the number of factors," Multivariate Behavioral Research, vol. 1, pp. 245-276, 1966.

[3] WHO, "Guidelines for Drinking Water Quality. Recommendations, 2004".

[4] WHO, "Fluoride in drinking-water," in A Series of World Health Organization Monographs, K. Bailey, J. Chilton, E. Dahi, M. Lennon, P. Jackson, and J. Fawell, Eds., IWA Publishers, Geneva, 2006.
[5] E. S. Johansen, The effects of fluoride on human health in Eastern Rift Valley, 2013.

[6] T. C. Davies, "Chemistry and pollution of natural waters in western Kenya," Journal of African Earth Sciences, vol. 23, no. 4, pp. 547-563, 1996.

[7] D. M. Deocampo, "Hydrogeochemistry in the Ngorongoro Crater, Tanzania, and implications for land use in a World Heritage Site," Applied Geochemistry, vol. 19, no. 5, pp. 755-767, 2004.

[8] K. F. Nair, F. Manji, and J. N. Gitonga, "The occurance and distribution of fluoride in ground waters of Kenya," IAHS Publ, vol. 144, pp. 75-86, 1984.

[9] J. T. Nanyaro, U. Aswathanarayana, J. S. Mungure, and P. W. Lahermo, "A geochemical model for the abnormal fluoride concentrations in waters in parts of northern Tanzania.," Journal of African Earth Sciences, vol. 2, no. 2, pp. 129-140, 1984.

[10] P. Kilham and R. E. Hecky, "Fluoride: geochemical and ecological significance in east african waters and sediments," Limnology and Oceanography, vol. 18, no. 6, pp. 932-945, 1973.

[11] L. P. Pauling, The Nature of Chemical Bond and the Structure of Molecules and Crystals: an Introduction to Modern Structural Chemistry, Cornell University Press, New York, NY, USA, 1960.

[12] J. D. Hem, Study and Interpretation of the Chemical Characteristics of Natural Water, Water Supply Paper 2254, Washington, DC, USA, 3rd edition, 1989.

[13] S. P. S. Teotia, M. Teotia, and R. K. Singh, "Hydro-geochemical aspects of endemic skeletal fluorosis in India - An epidemiologic study," Fluoride, vol. 14, no. 2, pp. 69-74, 1981.

[14] U. Aswathanarayana, P. Lahermo, E. Malisa, and J. T. Nanyaro, "High fluoride waters in an endemic fluorosis area," in Proceedings of the International Symposium on Geochemistry in Health, Royal Society, 1986.

[15] WHO, "Fluoride in drinking-water back ground document," Multivariate Behavioral Research, vol. 1, pp. 629-637, 1966.

[16] A. J. Mcharo, The Occurrence and Possibilities of Fluoride Removal in Arusha Area, Tanzania, Tampere University of Technology, 1986.

[17] J. S. M. Mungure, A collective Study of Incidences of Fluorosis and Possible Fluoride Sources in Maji ya Chai in Arumeru District, Arusha Region, Tanzania, University of Dar es Salaam, Tanzania, 1984.

[18] H. Mjengera, Excess Fluoride in Portable Water in Tanzania and the Defloridation Technology with Emphasis on the Use of Polaluminium chloride and Magnesite, Tampere University of Technology, 1988.

[19] G. Ghiglieri, R. Balia, G. Oggiano, and D. Pittalis, "Prospecting for safe (low fluoride) groundwater in the eastern african rift: the arumeru district (northern Tanzania)," Hydrology and Earth System Sciences, vol. 14, no. 6, pp. 1081-1091, 2010.

[20] G. Ghiglieri, D. Pittalis, G. Cerri, and G. Oggiano, "Hydrogeology and hydrogeochemistry of an alkaline volcanic area: The NE Mt. Meru slope (East African Rift-Northern Tanzania)," Hydrology and Earth System Sciences, vol. 16, no. 2, pp. 529-541, 2012.

[21] J. Mkungu, "Application of Soil Composition for Inferring Fluoride Variability in Volcanic Areas of Mt. Meru, Tanzania," International Journal of Environmental Monitoring and Analysis, vol. 2, no. 5, p. 231, 2014.

[22] R. J. Hijmans, S. E. Cameron, J. L. Parra, P. G. Jones, and A. Jarvis, "Very high resolution interpolated climate surfaces for global land areas," International Journal of Climatology, vol. 25, no. 15, pp. 1965-1978, 2005. 
[23] UNDP, Arusha Region Water Master Plan, Final Report, 2000.

[24] F. Gea, Analysis of Issues Connected with Water Supplying in Maasai Pasturelands Around the Village of Uwiro (Arusha, Tanzania), Graduation Thesis University of Torino, 2005.

[25] IAEA, Environmental Isotopes in the Hydrological Cycle Principles and Applications Environmental, vol. 1, International Atomic Energy Agency (IAEA) and United Nations Educational, Scientific and Cultural Organization, 2000.

[26] V. K. Saxena and S. Ahmed, "Dissolution of fluoride in groundwater: A water-rock interaction study," Environmental Geology, vol. 40, no. 9, pp. 1084-1087, 2001.

[27] J. V. Walther, "Comment and reply: Feldspar dissolution at $25^{\circ} \mathrm{C}$ and low pH," American Journal of Science, vol. 297, no. 10, pp. 1012-1032, 1997. 

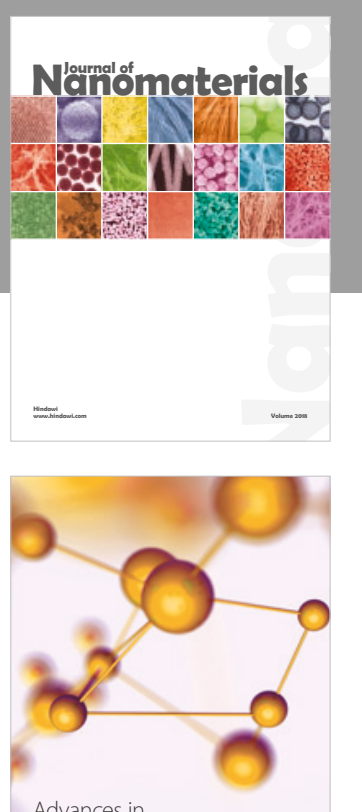

Physical Chemistry
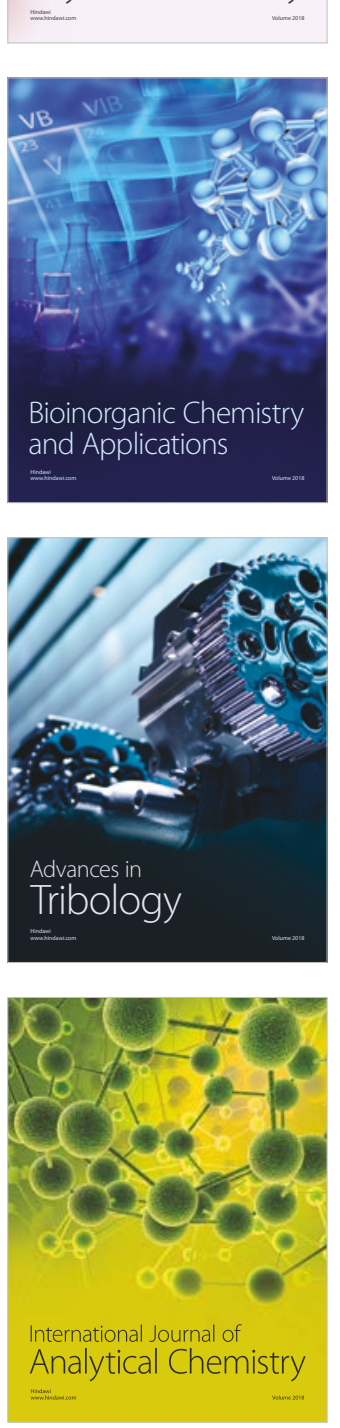

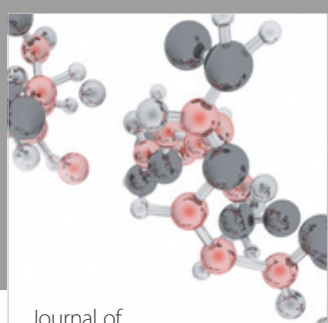

Analytical Methods

in Chemistry

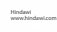

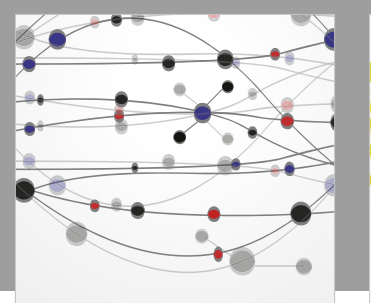

The Scientific World Journal

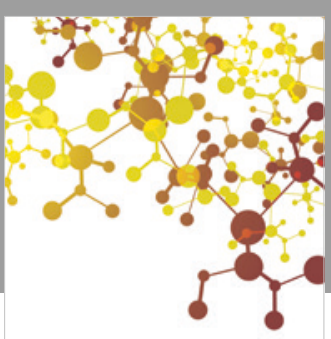

Journal of

Applied Chemistry
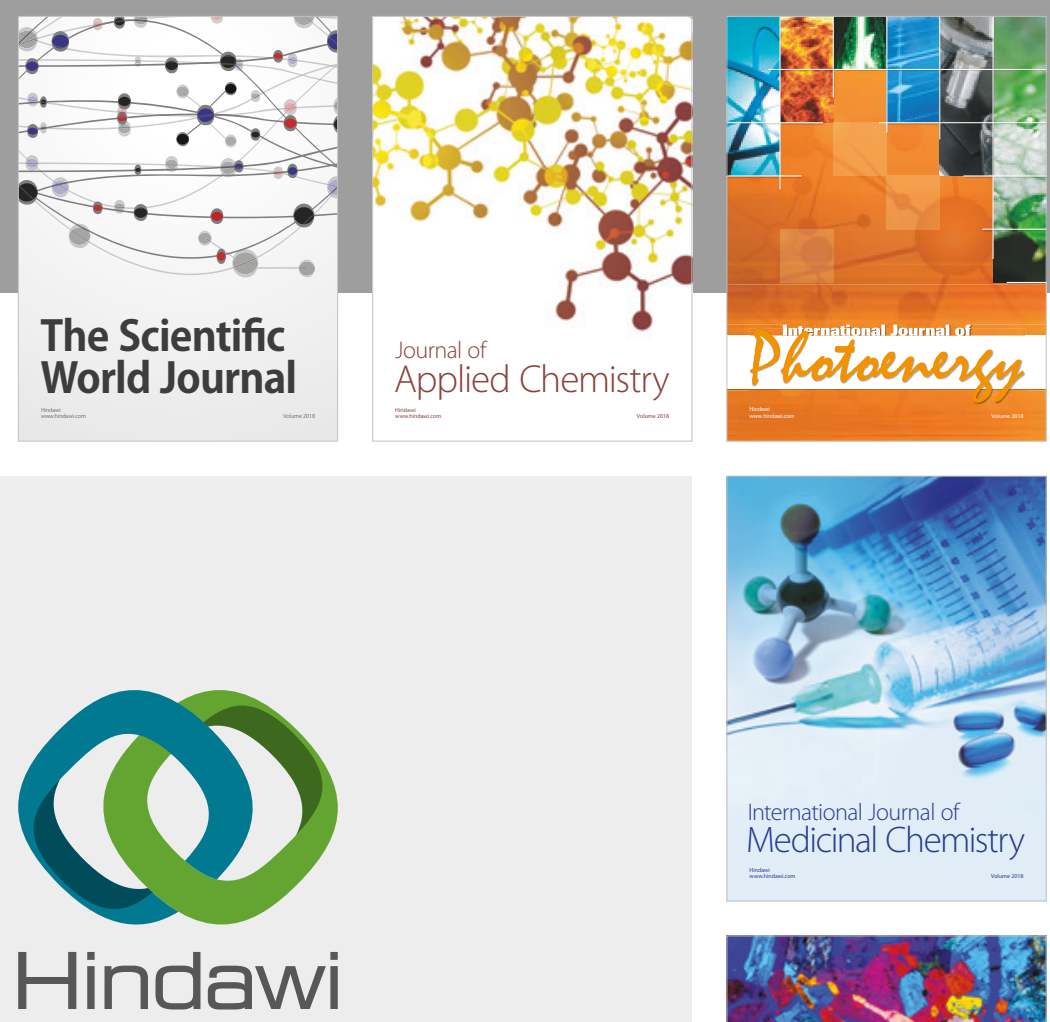

Submit your manuscripts at

www.hindawi.com
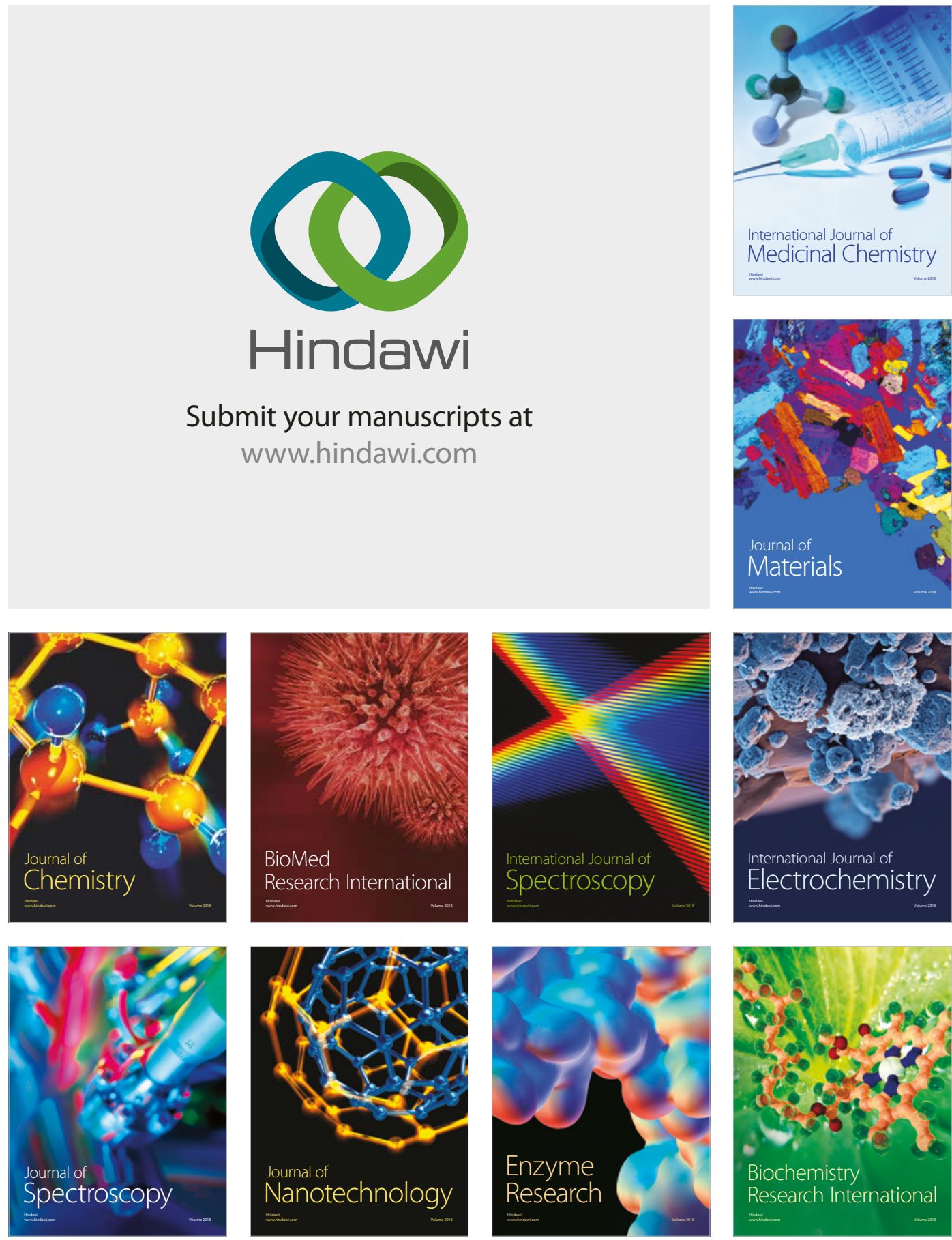
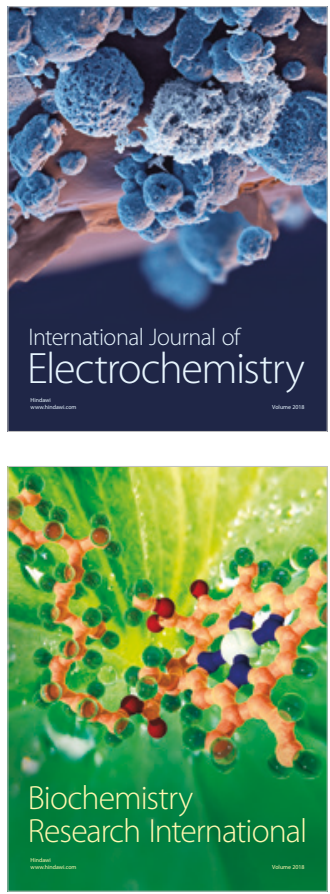